Tertiary basins of Spain

the stratigraphic record

of crustal kinematics

Edited by

PETER F. FRIEND AND CRISTINO J. DABRIO

$(1996)$

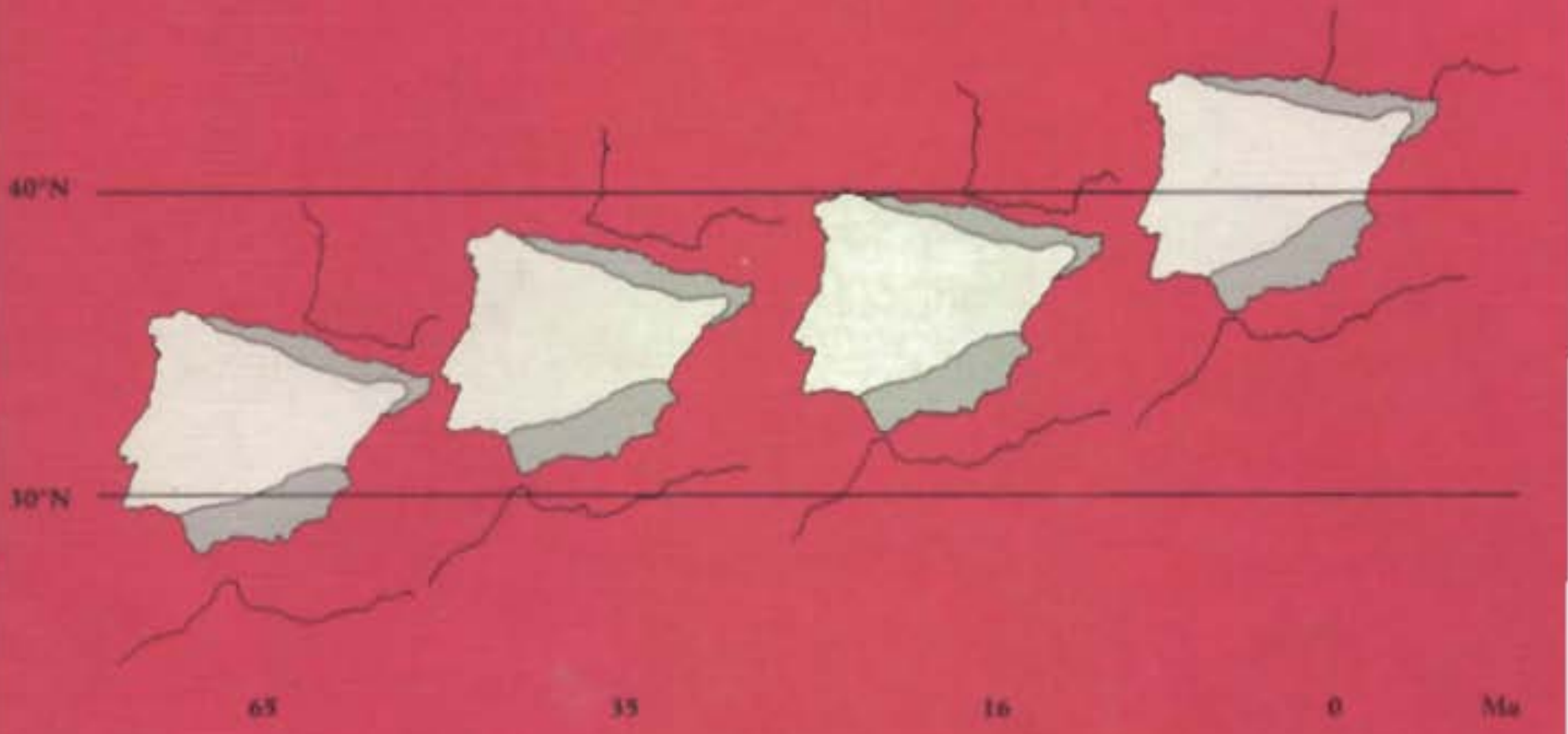

World and Regional Geology 6

CAMBRIDGE UNIVERSITY PRESS 


\section{Tertiary basins of Spain}

the stratigraphic record of crustal kinematics

EDITED BY

PETER F. FRIEND

Demariment of Earth Sciences, University of Cambridge

AND

CRISTINO J. DABRIO

Departamento de Estratigrafina, Facultad de Cienctas Geológicas and Instituto de Geologia Económica, CSTC, Universidad Complutense, Madrid, Spain 
Published by the Press Syndicate of the University of Cambridge

The Pitt Building, Trumpington Street, Cambridge CB2 IRP

40 West 20 th Street, New York, NY 100114211 , USA

10 Stamford Road, Oakleigh. Melboume 3166, Austratia

C) Cambridge University Press 1996

First published 1996

Printed in Great Britain at the Unversity Press, Cambridge

A catalogue record for this book is available from the British Lobrat:

Library of Congress catalogwine in publication dakt

Tertiary basins of Spain : the stratigraphic record of crustal kinematics / edited by Peter F. Friend and Cristino I. Dabrio. p. cm. - (World and regional geology series)

Inciudes bibliographical references.

SBN 052146171.5

1. Geology, Stratigraphic "Tertiary. 2. Geology, Structural -

Spain. 3. Basins (Geology) - Spain. I. Friend, P.F II. Dabric.

Cristino J. III. Series.

QE691 T465 1995

$551.780946-\mathrm{dc} 20 \quad 94-21724 \quad$ CIP

ISBN $052146 / 7$ I 5 hardback 


\title{
G6 Mineral resources of the Tertiary deposits of Spain
}

\author{
M.A. GARCÍA DEL CURA. C. D. DABRIO AND S. ORDÓÑEZ
}

\begin{abstract}
Spain is the most self-sufficient country for mincrals in the EU. A major proportion of these Spanish mineral resources has been obtained from Tertiary materials. The main materials exploited in Tertiary basins have been: brown coal and lignites. potassium salts, sodium salts (sulphates and chlorides), diatomite. sepiolite and other absorbent clays, bentonites, celestine, pumice. and atso dimension (building-) stones and ceramics, portand cement and plasier raw materials.

$P b-Z n-A g$ and gold alwite volcanogenic ores. related to Neogene volcanism, besides Au-placers have been mined from Roman times. Minor $\mathrm{Cu}$ and $M n$ occurrences are also reviewed.

The brown coal mines of Galician basins have provided all the significant production of Spain: more than 17 ML. Low-quality Oligocene lignites in the eastern part of the Ebro Basin and Balearic Islands are less important from the economic point of view. Other occurrences are in the Guinzo de Limia. Guadix Baza. Gratadi (Arenas del Rey) and Alcoy basins.

The Spanish Tertiary basins (continental and marine) (Oligocene-Miocene) are filled by thick evaporites in which are obtained potassium salts and sodium salts (sulphates and chlorides). The Montevives celestine mine is located in the evaporitic unit of the Granada basin (Miocene), and provides all of the Spanish celestine production. Spain is the world's third largest producer of celestine.

The Madrid basin and the minor Calatayd basin supply the whole of Spanish sepiolte production. The most important Spanish attaputgite production is obtatned from the El Cuervo mine (Sevilla and Cadiz provinces). The genesis of the Cabo de Gata bentmite deposits is thought to be by hydrothermal alteration and halmyrolsis of Neogene volcanic rocks. The Madrid basim bentonites and pink clays" have been interpreted as an eary diagenetic. even edaphic Mgrich, attapulgitization of illite clays. The most important areas of ceramic clay production in Spain are located in the Guadalquivir basin (Balen area) and the Madrid basin (La Sagra Alcalá de Henares).

The continental Neogene basin of the Hellin area supplies $90 \%$ of Spanish diatomite production.
\end{abstract}

\section{Introduction}

The estimated value of mineral production (oil and gas excluded in 1990 in Spatn was about $\$ 4325$ million, which represented over $1 \%$ of the country"s Gross National Product. With a level of supply estimaicd at $35 \%$ of the domestic consumption of mineral raw materials, Spain is the most selifsufficient country in the EU/Manana. 1992:

In 1990 the whole production of brown coal (20.9 Mt), potassium salts $(0.78 \mathrm{Mt})$. sodium sulphate salts $(0.71 \mathrm{Mt})$, bentonites $(0.15$ Mt), sepiolite-attapulgite $(0.56 \mathrm{Mt})$, diatomite $(93 \mathrm{kt}$, celestine $(80)$ $\mathrm{kt}$. and pumice was extracted from Terliary rocks (TGE, 1992). The Tertiary basins also provide a large proportion of lignites. natural stones, including commercial marbles, ceramic raw materiats. coment raw materials (limestone, clays and gypam), aggregates (crushed limestone and basalt) and gypsum for plaster manufacture.

This chapter presents a review of the most important mines, both active and historical, and occurrences located in - or related to - the sedimentary rocks of the Tertary basins in Spain.

\section{Metallic ores}

The most important ore seposits are the Zhim $P h$ m At volcanogenic stockworks (nctwork ore-bodies) mined in Neogene volcanic rocks in south-eastern Spain (Fiv. 1). The origin and interpretation of these ore deposits are controversial, but in all cases the Neogene vulcanism played an essential role in the ore genesis (Manteca \& Ovejero, 1992). Siver has beer minced sinee Roman times in La Unión-Cartagena district. Supergene enriched eatbonates and sulphides in gossans were mined in the ninctecrth centurs. The main denosits mined in this district are lead, silver, zine. and minor baryte and iron ores. After the Spanish civil war. the production of the disiriet rose to $90 \mathrm{Mt}$. producing lead $(1.2 \mathrm{Mt})$. zine ( $1.6 \mathrm{Mt}$ ) and silver (1.5 $\mathrm{kt}$. Two Pb $\mathrm{Zn}-\mathrm{Ag}$ slockworks have been described recently in the Mazarron district: one of these deposits contains $2.9 \%$ zinc, $1 \%$ lead, 28 gt siver and $9 \mathrm{ML}$ ore. and the other contains $2.3 \%$ zinc, $0.7 \%$ lead, $20 \mathrm{~g} / \mathrm{t}$ silver in a $5 \mathrm{Mt}$ orc (Rodriguez, 1992). 


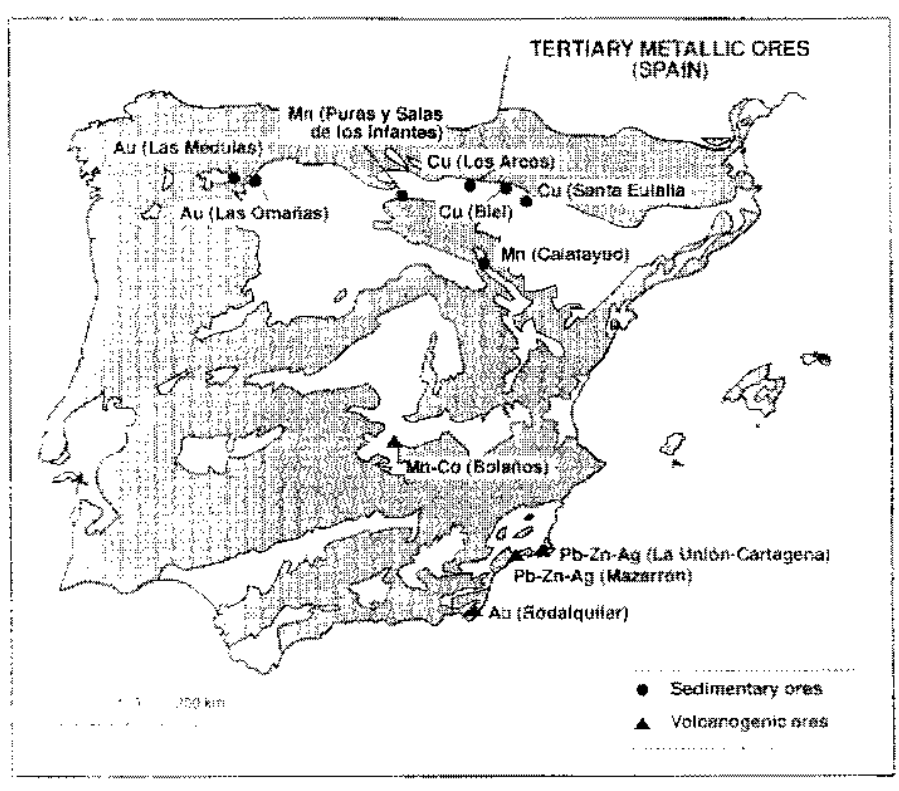

Fig. 1. Sehernatic location map of Tertiary metallie ares (see text).

The Rodalquilar golti-alunice field is related to calderas in the Cabo de Gata Neogene volcanic area (Fig. 1). Arribas Rosado (1992) described ore grades up to $10 \mathrm{gtt}$ Mined since 1970s, its production reached $85 \mathrm{~kg}$ in 1989.

The NW Iberian Peninsula, NW of the Duero Basin and the El Bierzo Basin, was mined for gola in Roman times (Pérez Garcia Sanchez Palencid. 1985, 1992). More than $7 \times 10^{\mathrm{s}} \mathrm{m}^{3}$ of goldbearing scdiments have been removed in over 600 mines. The total amount of gold exploited by the Romans in the alluvial doposits was about 200 t (Porter \& Alvarez Moran, 1992). Gold grades up to $300 \mathrm{mg}$ An $\mathrm{m}^{3}$ have been described in the alluvial fan deposits of the Las Medulas Formation in the Bierzo Basin (see Chapter W9) Channel fill deposits contain gold flakes over 70 microns across (Pérez Garcia \& Sánchez Palencia, 1985). There are reports of gold grades up to $50 \mathrm{mg} \mathrm{Au} / \mathrm{m}^{3}$ in the Omanas Formation in the northem Duero Basin.

Some copper occurrences have been described in the Oligocene conglomerates of the north Ebro basin. The main ore minerals are cuprite. calcosine, galena and native copper, all them related to granular cementation of conglomerates. Ore deposition is thought to be induced by the oxidising action of infiltrational water on the formation waters of the Oligocene sediments. The thickness of individual conglomerate layers reaches $8 \mathrm{~m}$. The major oocurrence is the Biel Mine (Zaragoza), with estimated reserves about $500 \mathrm{kt}$ and copper contents around $1.7-2 \%$.

Small axide-hydroxide manganese ores have been mined in the Campos de Calatrava (Bolanos district) since the nineteenth century, (Crespo Zamorano, 1988 a and b). The ore deposits are reiated to Pliocene alluvial-fan sediments of the Guadiana Basin. Manganese ores occur as granular cement in conglomerates and also as manganiferous crusts. Both types may be related to lowtemperature thermal waters derived from the Campos de Calatrava

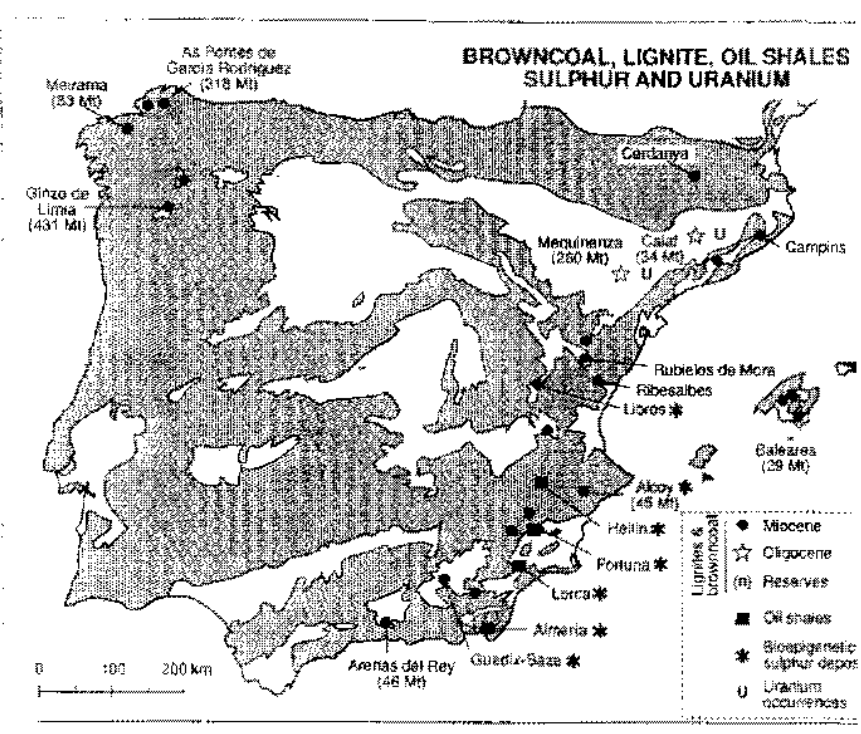

Fig. 2. Schematie location map of brown coal lignites and sulphur deposits, an oil shales and uranium occurretes (see text).

vulcanism. Grade in these ores reaches $3.59 \%$ manganese, an $0.051 \%$ cobalt, with inferred resources of $15.6 \mathrm{Mt}$ (Crespo Zamor ano. 1988 and b). Occurrences of manganese oxides-hydroxides a granular cement ores have been cited in the western part of the Ebr and Calatayud basins.

\section{Lignites, brown coal, oil shales and related sulphur and uranium}

At present, the Tertiary basins of the Iberian Peninsal produce up to $17 \mathrm{Mt}$ per year of brown coal, and some importan quantities of lignite (Fig. 2). Spain was the second largest sulphur producing country in Europe during the first part of the presen century and the Tertiary basins were the main suppliers of thi production. In the 1970 s native sulphur mining stopped as . consequence of sulphur recovery as a bi-product of oil and ga desulphuration.

The sulphur brimstone was obtained from bioepigenetic sulphu deposits. The $1912 \mathrm{Spanish}$ sulphur production was $14 \mathrm{kt}$, and at th same time laly, the European leader, reached a production of $60 \mathrm{k}$ The most important sulphur mines since Roman times are locate in Coto Menor (Hellin basin). Up to eight sulphur seams, less tha I m thick, have been exploited, with a $16 \%$ sulphur content. At th height of its activity this mine produced more than $50 \mathrm{kt}$ per yeat The rock age of the Hellin sulphur deposits is Late Miocene Pliocene. Other bioepigenetic sulphur deposits and occurrence have been described in the Baza, Fortuna, Lorca and Almeri basins (Reyes et al. 1992), the Libros basin (Anadón et al., 1989 ) and Alcoy (Reyes, pers. commun.).

The increase of crude oil prices since 1971 has resulted in th increase of oil shale and coal exploration in the Tertiary basin (Reyes \& Feixas, 1984; Reyes \& Crespo, 1984). Laminated oil shale in the Neogene basins of SE Spain (Almeria, Fortuna, Lorea 
Table 1. Properties of oil shale deposits in the Cerdanya, Campins, Ribielos and Libros basins of eastern Spain (see Fig. 2 for the location of these basins)

\begin{tabular}{lllll}
\hline \hline Basin & Age & $\begin{array}{l}\text { Thickness } \\
(\mathrm{m})\end{array}$ & $\begin{array}{l}\text { TOC } \\
(\%)\end{array}$ & $\begin{array}{l}\text { Yield } \\
(1 / \mathrm{t})\end{array}$ \\
\hline Cerdanya & Middle to Late Miocene & 250 & $>5$ & - \\
Campins & Upper Oligocene & 150 & 11.5 & 50 \\
Ribesalbes & Lower Miocene & 100 & $1-15$ & 87 \\
Rubielos & Lower Miocene & 250 & - & 30 \\
Libros & Upper Miocene & 10 & $1-2.6$ & $20-70$ \\
\hline
\end{tabular}

Note:

$\mathrm{TOC}=$ total organic carbon.

Table 2. Uranium reserves in lignite seams of the Calaf, Sta. Maria de Querall (village to the SSW of Calaf, and Mequinenza areas (see Fig. 2 for locations)

\begin{tabular}{lll}
\hline \hline Area & Reserves' $^{\prime}$ & Resources $^{1}$ \\
\hline Calaf & 15.3 & 26.3 \\
Sta Maria de Queralt & 13.6 & 26.3 \\
Mequinenza - Fraga - Almaret & 51.9 & 93.4 \\
\hline \hline
\end{tabular}

Note:

${ }^{1}$ Reserves US $\$ 15-30 / 10 \mathrm{U}_{3} \mathrm{O}_{8}$

Hellin), located in a marine pre-evaporitic environment of Tortorian-Messianian age, have been described (Reyes et al., 1984). On the other hand, Anadon et al. (1989) have described some oil shate occurrences in the Cerdanya, Campins, Ribesalbes, Rubielos and Libros basins (see Fig. 2). Some technical properties - TOC (total organic carbon), oil yield (1/t) and geological data (age. oil bearing shales unit thickness) - have been included in Table $\mathrm{L}$.

Radioactivity anomalies in the lignite seams of the Calaf and Mequinenza areas (Ebro basin) (Ramirez Ortegar, 1966) led to the investigation of the uranium contents and distribution in these Tertiary basins. As a result of this exploration, the uranium resources of the lignite seams of both basins have been estimated as up to $80.8 \mathrm{kt}$ of $\mathrm{U}$ (which sells at US $\$ 15-30$ per pound of $\mathrm{U}_{3} \mathrm{O}_{8}$ ) (Martín Deigado, 1975) (Table 2). At present, severe difficulties in extracting uranium from iignites, in addition to the availability of important Spanish high-quality uranium in proven quantity, make these Tertiary deposits uneconomic.

\section{Fossil fuels (oil and gas excluded,}

\section{Brown coals of the Galicta basins}

Several Tertiary basins occur along two dextral slip fauh zones in NW Spain. Brown coals were formed in the terrigenous deposits of these basins, as a result of the evolution of the alluvial and limnic systems. The largest coal deposits recorded so far in the zone occur in the As Pontes de Garcia Rodriguez and Meirama basins (littoral basins) and the Xinzo da Limia basin (SE Galicia) (sec Chapter W9), The age of the Tertiary coal-bearing sediments is not clear, because there is a controversial disparity in the dates interpreted from mammal vertebrate biozonation and from palynological biozonation (Chapter W9).

As Pontes de Garcia Rodrigue basin This basin is located in the NW-SE-striking structural corridor that extends for $55 \mathrm{~km}$, via Pedroso - As Pontes - Moinonoro (Santanach et al, 1988). It is an elongate basin with $7 \mathrm{~km}$ maximal length and a width varying from 1.5 to $2.5 \mathrm{~km}$ (Bacelar et al., 1991). As mentioned earlier, the As Pontes basin is a compressional basin partly controlled by a dextral strike-slip fault. The sedimentary fill was atternately overthrust by, and onlapping. the Hercynian basement during the successive deformation phases. The coal seams appear to have formed as a consequence of relative restriction and expansion between the limnic and alluvial systems in response to the varying subsidence of the deformation phases. Two depocentres developed in the basin: one located in the NW, the West Field, and another located in the SE, the East. Field. The fill of the As Pontes basin has been divided into four sedimentary units represented in both coal fields. The thickness of individual seams varies from 0.5 to $25 \mathrm{~m}$. and dispiays continuity along the basin. although there are lateral changes to terrigenous sediments in the marginal facies. In the basin. 19 coal seams have been identifed. Three main lignite types have been distinguished: brown coal, xiloide and pyropisitic lignile. the last mainly formed by resins. The virinite reflectance variss from 0.1 to 0.4 , the average being 0.3 (Martín Calvo. 1973). The average calorific value varies from 1600 to $2200 \mathrm{kcal} / \mathrm{kg}$. The waste: lignite ratio average in the open pit mines is up to three. The 1979 reserves of the As Pontes basin were $218 \mathrm{ML}$. and the 1989 lignite production in the basin was $12.6 \mathrm{Mt}$.

Meirama basin This basin is located in the NW-SEstriking structural corridor via Lendo-Mejama-Baimil (Santixnach et al., 1988). The surface area of the basin is about $1.5 \mathrm{~km}^{2}$; it has an elongate shape, with a long axis length of about $2.6 \mathrm{~km}$. parallel to the main dextral strike-slip lault. The thickness of the basin fill is up $10250 \mathrm{~m}$ and it is longinudinaly foded. The production in 1989 was estimated as up to $5 \mathrm{ML}$. and the proved resources are nearly $80 \mathrm{Mt}$.

Xinzo da Limia busin Thes basin ss located in the Villalba-Maceda-Xinzo da Limia structural lincation. which trends NNE-SSW. The sediment fill of the basin is up to $250 \mathrm{~m}$ thick. and up to $130 \mathrm{~m}$ of this may be lignite seams. The quatity of the lignite is brown coal, and the proven reserves may attain 431 Mt. The economic potential of the deposit was investigated recently by ENDESA (Baltuille, pers commun.).

\section{Lignites of the Ebro Basm}

Several coal sequences develored in Oligocene times in the Tertiary Ebro basin. Despite the fact that the individual seans of coal are thin and subeconomic, mining has taken place since the nineteenth century in the Caial and Mequinenza areas. In both 
areas, the organic biomarkers identified by Gorch et al. (1902) show that the original organic matter derived mainly from higher pants and bactoriat.

Cala we The coal-bearing stratigraphic section formed in the Sewara lacustrine system and consists of bmestones. marls terrigenous and even evaportic sediments of Early Oligocone age (Gorch $t$ th. 1992). The paludine-lacustrine, cod-bearing intervals consist manly of imestone and grey mudstone beds that intertinger wh lenticular channd-fill sandstones showing crosisbedding and ripple laminations. The grey massive mudstones are interbedded wh tod seams ranging from a few ontratres to $0.8 \mathrm{~m}$ in thickness. Organo-sulphur compounds (Gorch et al. 1992 are munly responsible for the high sulphur content of the lignites. The cols conwst many of lignite to sub-bituminous coul with calorific wites that ary from 6.400 to $7.042 \mathrm{kgl} / \mathrm{kg}$ (Cabrer 8 Saez. 1987 . a sulphur content that varies from 2.98 to $8.36 \%$ and ash content runging trom $16.46 \%$ to $24.18 \%$. The reserves in the Calat area are up 10 it Mt (IGME, 1985). From the petrological point of vew, the coals are vitrinite-rich with minor amounts of exinite and inertite. The vitrinte refectance ranges from 0.4 to 0.7 (Martin Cilvo. 1y33). This author pointed out the relationship between the uranum content and the organic matter content. and that uranium is proforentialy associated with humines and humic acid fractions. Local values of thp to $0.180 \% \mathrm{U}_{3} \mathrm{O}_{8}$ content have been recorded, alhough average values are nearer to $0.020 \%$ $\mathrm{U}_{3} \mathrm{O}_{\mathrm{z}}$

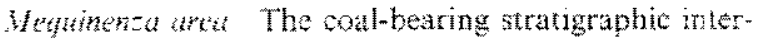
val formed in the Las Monegros lacustrine system and consists of limestones. mark, and evaporitic and terrigenous sediments of the Late Oligocene. The immodiate coal-bearing strata of the los Moncgros heustrine system consist mainly of pate brown to urey micritic limestones. grey mudstones and minor sandstone lenses and sheets. Thin lenticular coal sems interfinger with the lower and middle part of the unit. Individual seams ate generaly thin with shatp and well-defined boundaries. The average thickness is less than $0.3 \mathrm{~m}$ and varies from a few centimetres $60.9 \mathrm{~m}$. The coal deposits consist mainly of an ash-rich lignite. with $30-53 \%$ average ash content, a high sulphur content, ranging from 1.54 to $11.88 \%$ and calorific values ranging from 3,500 to $5.500 \mathrm{kcal} / \mathrm{kg}$ (Cabrera \& Sácz, 1987). The proven reserves are $260 \mathrm{Mt}$ (1GME, 1985).

Table 2 presents data on the uranium resources in both the Calaf and the Mequinenza coal areas.

\section{Other Tertiar coul basins}

The only mines active at present and not already discussed are in Baleartc Basins. These mines produce up to 14 ktiyear of lignite. The identified reserves of lignite in these basins are up to 71.4 $\mathrm{Mt}$, and the proven reserves are $29 \mathrm{Mt}$ ( $\mathrm{Fig} .2$ ).

In the Balearic Islands, lacustrine doposits have been described, of Early Oligocene. Ludian-Samoisian age (Colom, 1983) and of Middle Eocene age (Ramos-Guerrero et al., 1989). Only the deepest lacustrine facies of the central part of Mallotea contains lignite seams (Sta Maria, Binisalem. Alato, Inca, Loseta and Selva).

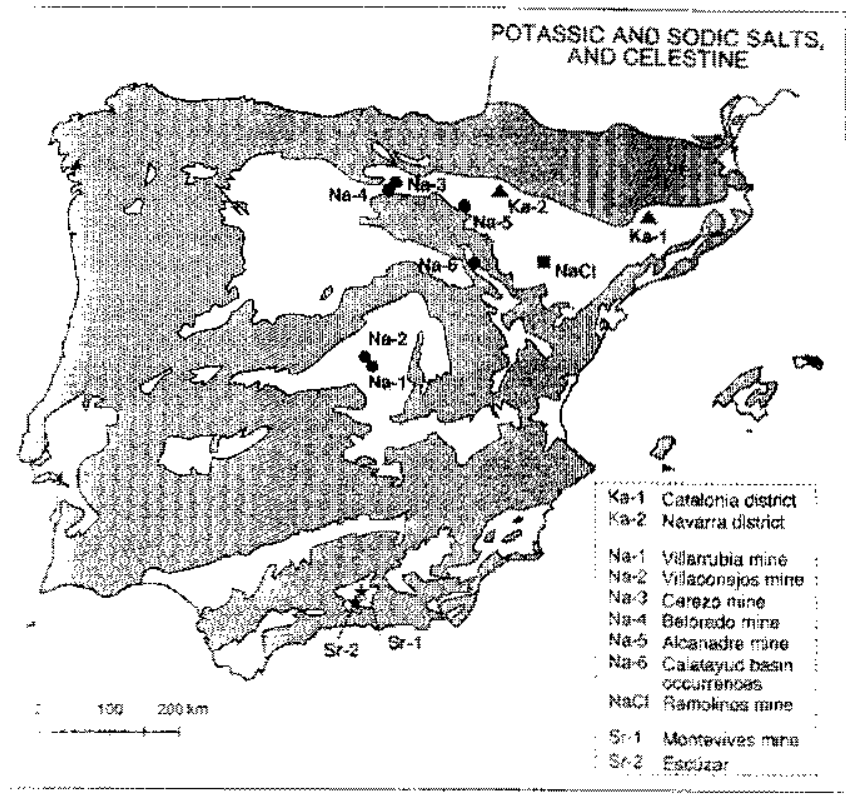

Fig. 3. Schematic location map of potassic salts, sodic salts and celestine mines (see text).

Recently. Ramos-Guerrero et al. (1989) have described the Binisalem member, which consists mainly of an alternation of limestone (bioclastic wackestone) and lignites. The coals consist mainiy of a humic matrix that contains exinic macerals, such as resinite and cutinte (Ramos Guerrero et al., 1989) with calorific values up to $4.6 \mathrm{kcal} / \mathrm{kg}, 1.7 \%$ sulphur content and $18.5 \%$ ash content $1 \mathrm{Colom}$. 19831 .

Lignite occurrences in Tertiary basins have been cited in the Cerdanya. Alcoy, Guadix-Baza and Cranada basins (Arenas del Rey). In the Prats-Alp area of the Neogere Cerdanya basin some lignite beds have been identified in unit $C$ of Anadon ta $a$ (1989) (Fig. 2). The lignite-bearing sediments of the Alcoy, Guadix-Baza and Granada basins have been reported as Late Miocene - Pliocene. Lignizes from the basins are mainly soft brown coals.

In the Neogene Madrid and Duero basins, in the fower evaporitic units. and also in the limnic shallow marly sediments, minor organic natter occurrenees (higrites and/or oll shales) have been cited.

\section{Potassic and sodic salts, and celestine}

Spanisin Tertiary basins, both continental and marine, contain thick evaporitic deposits from most ages of the Tertiary. Potassium salts, sodium salts (sulphate and minor chloride), celes. tine and gypsum are obtained from these Tertiary basins. In this section we focus on potassic and sodic salts and celestine. (Fig. 3).

\section{Potassic salts}

The Spanish production of potassic salts has decreased from $860 \mathrm{kt}$ of $\mathrm{K}_{2} \mathrm{O}$ in 1981 to $585 \mathrm{kt}$ in 1991 . All the production is concentrated in two mineral districts. Catalonia and Navarra. 
Table 3. Estimated mineral reserves of potassic salts in the Catalonia and Navarra districts

\begin{tabular}{|c|c|c|c|}
\hline \multirow[b]{2}{*}{ District } & \multicolumn{3}{|c|}{ Amount of resource $(\mathrm{kt})$} \\
\hline & Proven & Probable & Possible \\
\hline Catalonia & 10470 & 9185 & 16645 \\
\hline Navarra & 2000 & 8000 & 12000 \\
\hline
\end{tabular}

Source: From ITGE (1992).

Estimated mineral resources and reserves in these areas are presented in Table 3.

Salinity increased dramatically in the Sub-Pyrenean basin during the Late Eocene-Early Oligocene (Ludian). most probably it was this salinity crisis that was responsible for the deposition of potassic salts in the basin. Deep drill holes reach potassic salts in the central part of the Ebro basin below a thick cover of Oligosene-Neogene sediments. Pueyo (1975) and Rosell (1983) interpreted the deposition of salt as related to marine brine with a low content of magnesium sulphate. The basin underwent active nappe (overthrust) tectorics after the deposition of the salus and, according :0 Rosell (1983), the Catalonia district remained in the autochthonous zone, whereas the Navarrese district was transported by thrusting. As a result, erosion removed the seams of potassic salts in the cotes of the anticlines of the Navarrese district, while the anticlinal cores were preseryed in the Catalonis district under a thick cover of Oligocene sediments.

Catalonia district The structure of the Catalan district is an $\mathrm{E}-\mathrm{W}$-trending syncline, with salt thicknesses ranging from 150 to $\$ 00 \mathrm{~m}$ (Pueyo, 1975) as a consequence of local tectorics. In the Cardona diapir the thickness of potassic salts reaches $2000 \mathrm{~m}$. The main, and best-known mines (Cardona. Balsareny and Suriaj are located in this district.

The stratigraphic section includes, from bottom to top (Fig. 4):

1. Marine marls (Igualada marłs).

2. 4 to $5 \mathrm{~m}$, laminated anhydrite.

3. 130 to $200 \mathrm{~m}$. massive halite (sal de muro).

4. 5 to $20 \mathrm{~m}$, lower potassic unit, consisting of decimetro sequences of terrigenous clay carbonatcs, sulphates, halite and silvite. This unit is divided into wo by a thick layer of massive halite.

5. $401080 \mathrm{~m}$, upper potassic unit (carnalhic unit) including several seams three of four in the Suria mine, and more in other localities). It is interesting to note that the content of hahte (low-grade potassic salt) in this unit increases when the seams are thinner and less numerous.

6. 85 to $120 \mathrm{~m}$, grey mudstones, or ransition unit. Some intercalations of halite have been described in the lower part of this unit.

7. $500 \mathrm{~m}$ (or more), lacustrine reddish deposits (top).

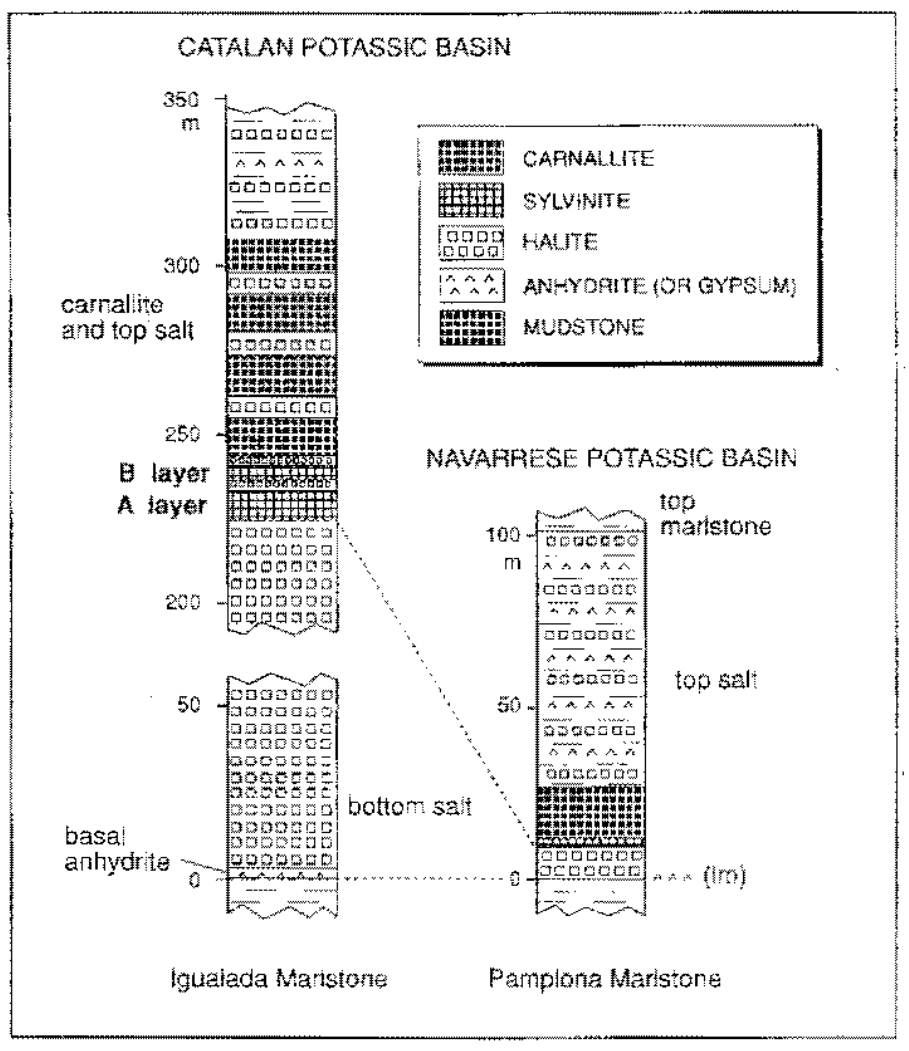

Fig. 4. Stratigraphic section correlation between Catalonian and Navarrese potassic basins. After Rosell (1983).

\section{Nawrese district}

As in the former case, the potassic salts are associated with marine marls (Pamplone marls). The oniy mine (Subiza shaft) is located in a synclinal basin (the so-called Pamplona potassic basin or Sierra del Perdon potassic basin), bat a research programme bas only recently been initiated.

A general stritigraphio succession inchudes:

1. Deep marine marls (bottom).

2. 0.6 to 1 m. laminared anhydrite urit.

3. Amost $10 \mathrm{~m}$. lower banded. massive hallite tnit (sal de muro)

4. $2 \mathrm{~m}$, lower potassic unit formed by 18 silvinite-halite couplets: some of therr are used as markers.

5. $12 \mathrm{~m}$. carnalitic unit, made up of eight halite-carnallit couplets.

6. Top halite unit, made up of sequences of decimetre- to metro-thick red mudstones and centimetrethick hatite layers.

7. Up $1050 \mathrm{~m}$, top marls. mudstones with some anhydrit: layers.

It should be noted that this strutigtaphic setion is very similar to the one in the Catabona district (Fig. 4). The only difference is the total thickness. 
Table 4. Reserves of yodum salts in Spunish mining distritus

\begin{tabular}{|c|c|c|c|c|c|}
\hline Company & Raw material & Pant location & Basin & $\begin{array}{l}\text { Extractive } \\
\text { method }\end{array}$ & $\begin{array}{l}\text { Proved reserve } \\
\text { (Mt) }\end{array}$ \\
\hline Crimidesa & Olatuberite & Cerzzo de Rio Tìnon & Ebro Trench & a & 19 \\
\hline Foret & Thenartite & Vilarrubia & Madrid basin & $b$ & 15.5 \\
\hline Minera S. Marta & Glauberite & Belorato & Ebro Trench & a & 63 \\
\hline Sutquisa & Glauberite & Villaconejos & Madrid basin & $\mathrm{a}$ & 57 \\
\hline
\end{tabular}

Notes:

(a) Open-pit solution; (b) underground mine.

Sotwe: From ITGE (1991)

\section{Sodium sults}

For many years, spain has been ihe European leader in natural soditum sulphate production. and all of it comes from Tertiary continental basins. The 1990 Spanish natural sodium sulphate production. in terms of $\mathrm{Na}_{2} \mathrm{SO}_{4}$ content. amounted to $7 / 4$ k. 34 kt from thenardite only in the Madrid basin, and the remander from glauberite in both the Madrid and Ebro basins. particularly the Tertiary Trench or Bureba Corridor in the western part of the Ebro basin (ITGE, 1992). Table 4 presents some data on the reserves of the mining districts.

There are two active mines in the Madrid basin (Fig. 5), one located near Villaconejos Colmenar de Oreja, and another located near the eightecnth-century mite in Villartubia de Santiago. There are many no-longer-active mines in the Madrid basin. but, in the past. the most common method of recovering salts was to use saline springs and wells tc.g. Espartinas. Carabana. Carcaballana. Loeches), and some of these were even being exploited in Roman times.

The mine located near Villaconejos-Colmenat de Oreja the Fátima miney, is an open-pit dissolution mine. The minerat glauberite is preferentially dissolved in poois located over a bed of glauberite anhydrite that is $27 \mathrm{~m}$ thick. The brine is recovered by pumping from wells and sent to an evaporation plant where topyuality sodium sulphate precipitates. The source brines of the evaporation plant are introduced into pools and then recirculated (Ordónez et ul.. 1982).

The mine located near Villatrubia de Santiago ( EI Castellar') is a pillar and room underground mine that works a $5-8 \mathrm{~m}$ thick thenardite bed with minor glauberite. The mineral extracted is processed in an evaporation plant to obtain the commercial sodium sulphate (Ordónez et $a t, 19 \times 2$ ).

The Neogene stratigraphic record of the Madrid basin is summarised by Megias et al. (1983) and by Calvo et at. (Chapter C2). The sodium suiphate mines are located in the lower Unit. The sedimentological interpretation of the Lower Unit or Saline Unit has been discussed by Ordonez et at. (1992) and by Ordonez \& Garcia del Cura (1995). The mineralogical and petrological features of the economic saline deposits have been described by Garcia del Cura (1979). Garcia del Cura elak. (1979) and Ortien al. (1979). The

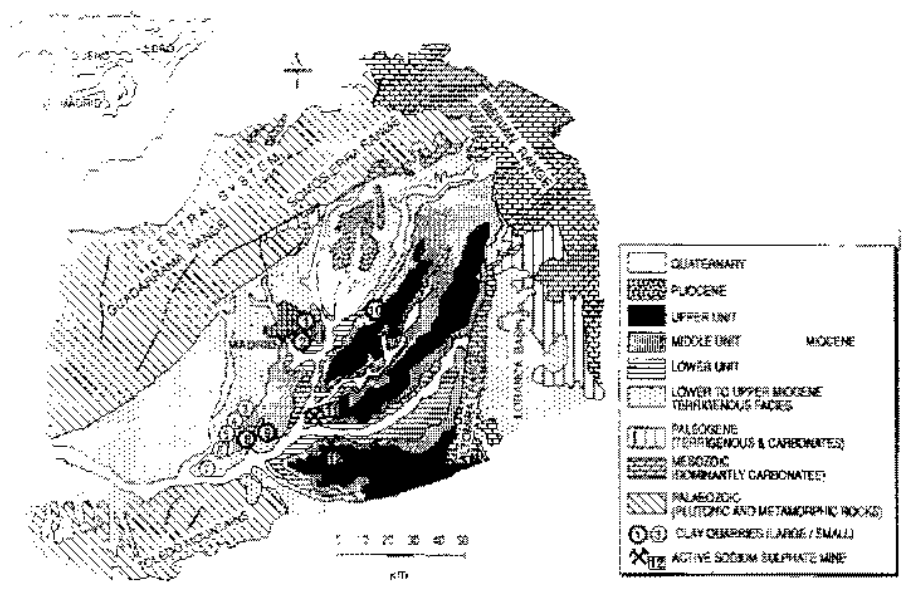

Fig. 5. Location map of main active mines in Madrid basin: 1. Vicalwaro sepiolite mine: 2. Almodóvar sepiolite mine; 3-6, Yepes-Cabañas de La Sagra mines (bentonites and sepiolite), 7,1 a Sagra ceramic raw clay mines; 8 and 9 , Fsquivias special clay mines; 10 Alcalá ceramic raw elay mines; 11 , Villaconejos ('Fatima mine') sodium stalphare mine (glauberite), and 12, Villarrubia ('El Castellar') sodium sulphate mine (glauberite and thenardite).

only paleontological data obtained from the Saline Unit are the flora found in an exploration drill hole near the Villaconejos mine. This fora indicates a Late Oligocene - Early Miocene age for the Saline Unit (Alyarez Ramis tal., 1989).

The "El Castallar mine is placed in the Upper Saline Subunit. The sedimentology and tacies distribution of this Upper Saline Subunit are poorly understood, and are, at present, under review by the authors of this chapter. However, it is possible to point out some distinctive features of this Upper Salme Suburit, one being the presence of thenardite as the main mineral, and another being the lowa and restricted character of this Subunit. In this Upper Subunit it s possible to identify at least six repetitions of the following sedimentary $d m$ to $m$ sequence: 1 . reddish mudstone containing interstitial halite; 2 muddy terrigenous sediment \pm halite \pm glauberite: 3 . massive thenardite \pm glauberite. The thenardite \pm glauberite bed mined in Villarrubia is up to $8 \mathrm{~m}$ thick (Fig. 6). The massive thenardite mined there displays a typical blue colour and is thought to be a secondary mineral from mirabilite. This soft 


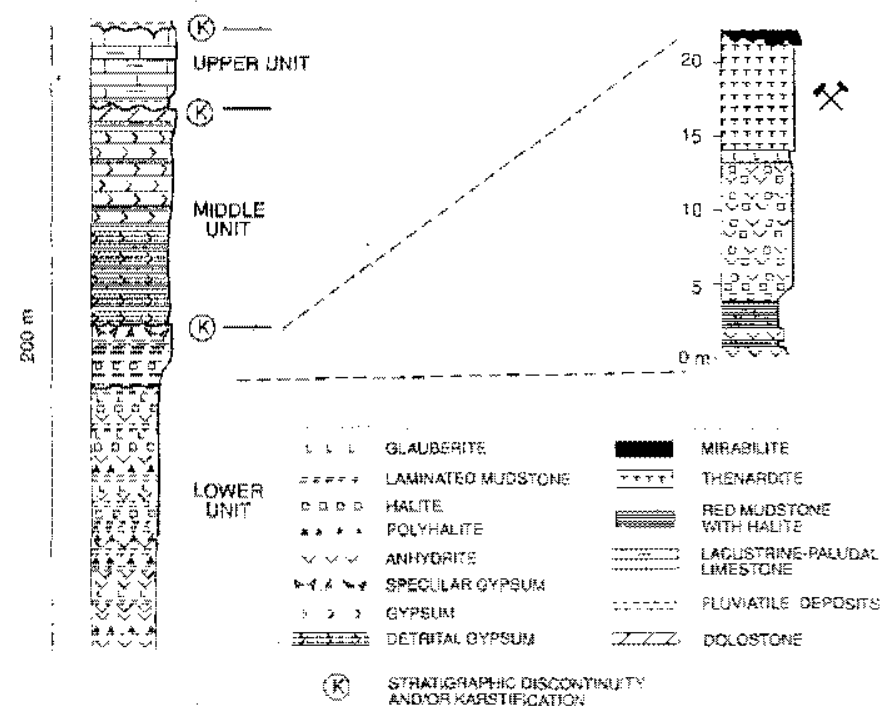

Fig. 6. Lacation of Villarrubia thenardite 5 giauberite mine. Stratigraphic section of central part of Madrid basin and a detalled section of thenardite seam mined there.

and wet crystalline mirabilite precursor of thenardite formerly contained some precpitaled idiomorphic crystals of glauberite that are now enclosed in nassive thenardite.

The glauberite mine of Villaconejos exploits the lower Saline Subunit (Fig. 7). This Subunit is thought to have formed in a perennial saline lake surrounded by a wide mudilat. As pointed out by Ordónez et al. (1983) and Utrila et al. (1992). brines of this saline lake were derived manly from the weathering of upper Cretaceous-Paleocene marine evaponites. Saline mineral associations in this stratigraphic interval are reported in Fig. 7. Glauberite oceurs as a massive bed of idiomorphic glauberite crystals, with minor magnesite marts interbedded with anhylnte and micritic magnesite. Glauberite cements and nodulat anhydritc have recently been interpreted to result from the early diagenetic glauberitisation of primary anbydrite in the muddy lacustrine belt during episodes of low lake water levels (Ordónez \& Garcia del Curu. 1993).

The Cerezo de Rio Tiron, Santa Mara and Belorado glauberite mines are located in the Tertiary Trench. "La Bureba Corridor". that connects the Ebro and Duero basins. Glauberite mines are located in the Cerezo Evaporite Formation of uncertain Late Miocenc agc. and are restricted to the central part of a small basin. The Evaporite Formation displays sharp lateral facies changes io non-economic detrital sediments through saline mudsiones with nodular anhydrite. A perennial saline model has been proposed to explain the general features of the Evaporite Formation (Menduina at al. 1984). The detrital sediments laterally associated with the saline deposits have been interpreted as the distal part of a prograding lacustrine deltaic system, and this model has been used in the exploration of the Santa Marta mine. which started production in 1989.

The recovery method used in Cerezo de Rio Tirón and Belorado is similar to that described in the Villaconcios mine that is tosay, an

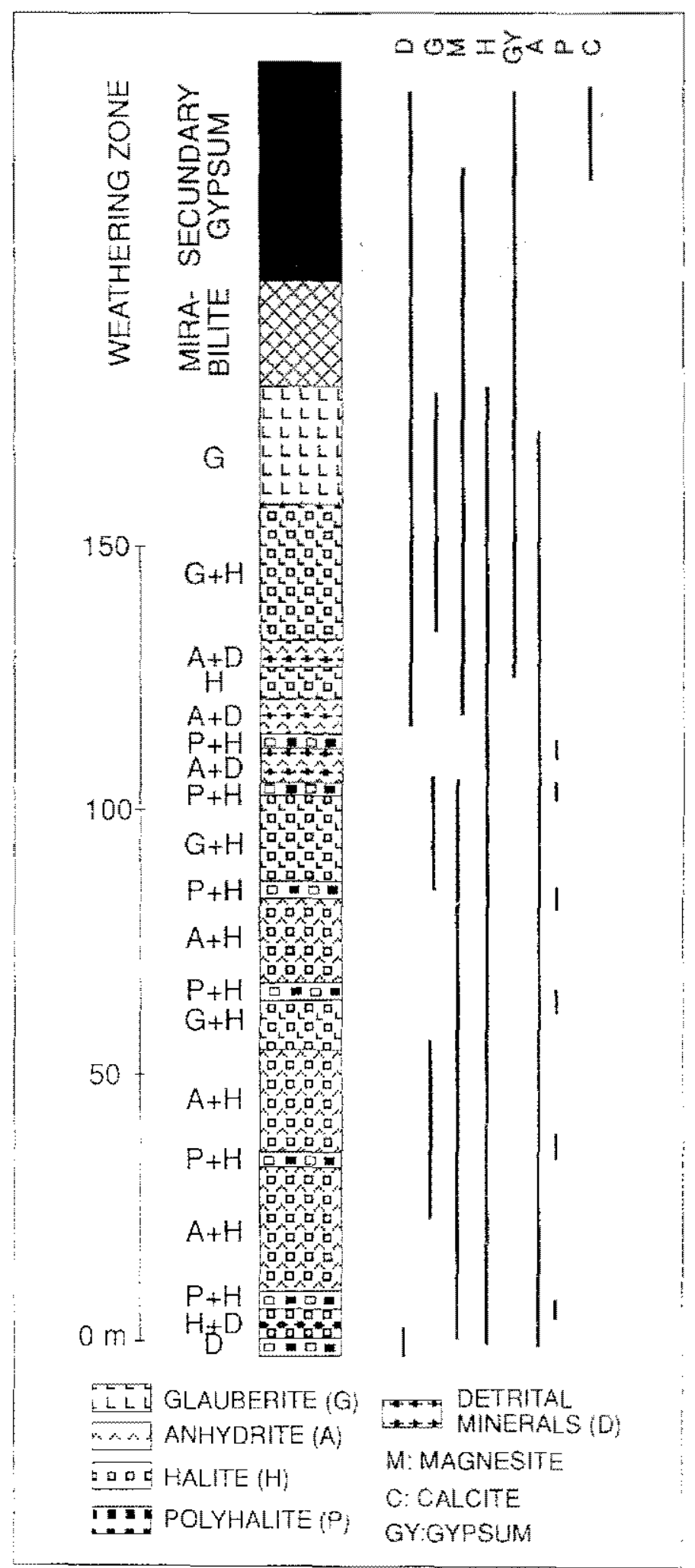

Fig. 7. Schematic mineralogical section of an exploration drill wole iscated close to the Vilaconejos glauberite mins. 


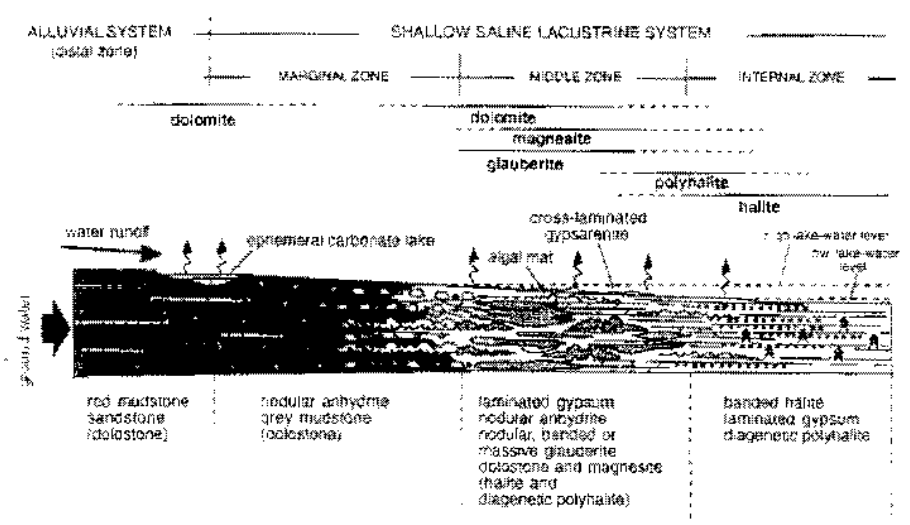

Fig. 8. Paleoenvironmettal and sedimentological model of Alcanadre nonactive mine. Adapted from Salvany \& Orti (1992).

open pit solution mine cut down to a glauberite seam: the resulting brine is the raw material for topquality commercial sodium suiphate.

The Corzo Eyaporite Formation stratigraphic interval contains alternations of metre-thick seims of microcrystaline glauberite and non-economic muddy anhydrite. The number of glauberite seans is up to eight, but the recovery methods, and the commercial produclivity of the seams, are conditioned by the present-day topograpiny and by the impoverishment of the upper seams by infiltration of mateoric waters.

Some no-longer-active underground mines with glauberite have been descubed from the western Ebro basin. These glaberite deposits are located in the Lerin Formation of Late OHgoceneEarly Miocene age (Salvany, 1984; Salvany \& Orti, 1992. 1994). These authors have recently proposed a paleogeographical and sedimentologital model to explain the main features of the Alcanadre mine zone (Fig. 8). The thickness of the overburden and the unnness of the glauberite beds result in high values of the stripping ratio and the submarginal cconomic character of these occurrences.

Some glauberite occurrences in the central part of the Ebro basin and below the halite beds of La Real mine (Rernolinos-Zaragoza) have been described (Fumández Nieto \& Gán, 1979: Garcia Veigas of 4 i. 1991). Some outcrops of glauberite beds have also teen reported in the Calatayud basin (IGME. 1980: Sánchez Moral et at.. 1993).

Halite rock salt is present in both continental and marine Tertiary basins of the Iberian Peninsula. The 1990 Spanish production of sodium chloride was $3.3 \mathrm{Mt}, 19.8 \%$ of which was obtained as a byproduct of Tertiary potassic salt reovery, and $3.2 \%$ was obtained from the Tertiary Ebro basin. A high proportion of the remainder was obtained from the natural evaporation of marine brines, and a smaller proportion from Triassic rock sait deposits. The rock salt deposits of Remolinos and Torres de Berrellen in the Zaragoza Formation (Lower Miocene) of the central part of the Ebro basin have been mined for a long time. Proved reserves amount to more than $16 \mathrm{Mt} \mathrm{NaCl}$. The halite deposit is up to $100 \mathrm{~m}$ thick, and consists of decimetre layers of balite with minor nodular anyhdite (Ori \& Pucyo. 1977). The lateral continuity of the deposit is over $30 \mathrm{~km}$ along the Ebro river valley (Orti, 1990 ).

\section{Celestine}

Spanish celestine production has risen from about $19 \mathrm{kt}$ in 1980 to more than $80 \mathrm{kt}$ in 1990 . Spain is the third country in the world ranking of production of this mineral, Celestine is produced from the Montcvives mine, about $12 \mathrm{~km}$ southwest of Granada (Cranada Province). The Montevives ore grade is $80 \% \mathrm{SrSO}_{4}$, with proven reserves of $3 \mathrm{Mt}$. The regularity of the ore body in this case anables the deposit to be competitively concentrated by the flotation method.

The Montevives mine is located in a smail hill in the central part of the Tertiary Granada basin. The host sedimentary materials are of Middle to Late Miocene age. Recently, Rubio Navas (1990) has pointed out the ncar domic structure of the ore body and the tectonic character of the celestine ore body outcrop.

The celestine ore is strata bound, up to $40 \mathrm{~m}$ thick, and it dips $20^{\circ}$ to $50^{\circ}$ lowards the northwest. The celestine mineralisation displays a mm-scale, clear-dark banded texture similar to the primary stromatolite textures of the host limestone and marls. The rich ore displays a massive structure and earthy and/or microcrystalline textures with obilteration of primary strictures. The ore body is wetl stratifed in layers ranging from 20 to $50 \mathrm{~cm}$ thick. In adition to celestine, the mineral paragenesis of the Montevives ore deposits includes calcite, dolomite, quartz. gypsum, strocianite, Fe-Mn oxides and hydroxides, phyliosilicates, etc.

The Escizar village celestine occurrence is an E-W-striking outcrop with more than $10 \mathrm{~km}$ lateral continuity - the Escuzar Celestine Belt of Martin et al, (1984). The host rock of the celestine ore is also a stromatolitic limestone, and the thickness of the deposit is roughly $20 \mathrm{~m}$. The average celestine content is lower than at Montevives, and ranely rises $1055 \%$. A significant feature of this cccurrence is the presence of a karstic surface at the top of the deposit, with dolines and other karstic depressions filled by lowgrade brecolated ore and stromatolite carbonates. Escuzar has xstimated reserves of about $1 \mathrm{Mt}$.

Both the Montevives and Escuzar celestine deposits have been interpreted as the results of carly diagenetic cementation of stromatolitic carbonates when dessication processes followed the fall in sea-level (Martin et al. 1984). In this model, the strontium is derived from marine connate waters.

Other celestine occurrences have been cited in the Duero Tertiary basin (Ordónez et al. 1980), and Ebro basin (Rubio Navas, 1990).

\section{Special clays (sepiolite, attapulgite and bentonites), ceramic clays and diatomites}

Sepiolite, attapulgite and bentonite deposits are commonly associated in the Tertiary clayey formations, and in consequence these minerals are mined together or in the same areas. The official statistical data of these special clays show some contradictory interpretations because the uses of the special clays are simitar 


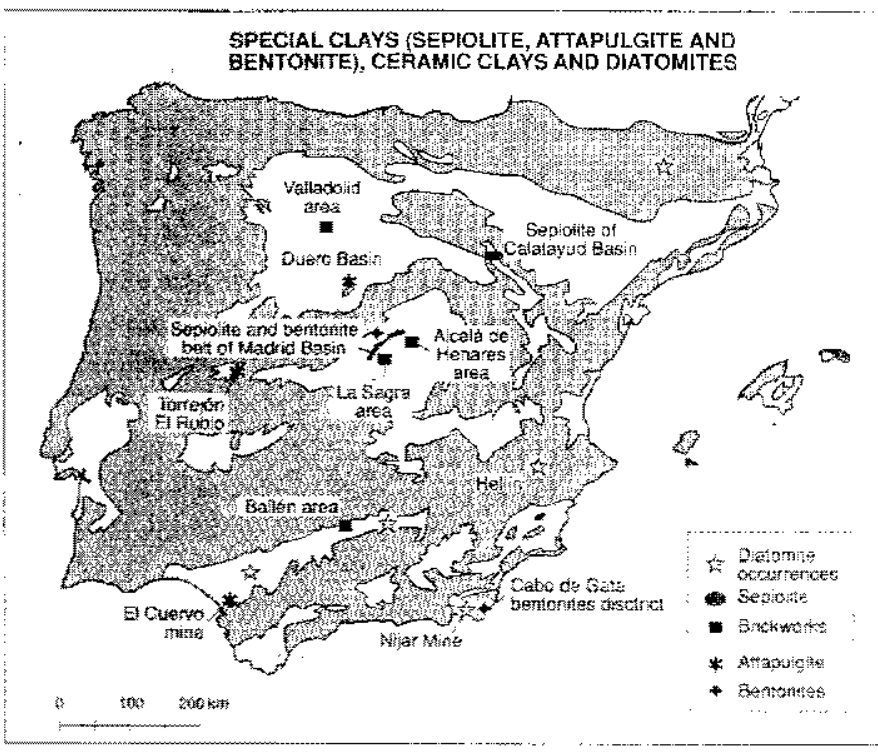

Fig. 9. Schenatic location map of special clays (sepiolite, attapulgite and bentonite), ceramic clays and diatomites (see text).

and generally connected with the physical properties of absorption. exchange capacity, etc. As a consequence, we also melude in this section the diatomite deposits because these physical properues are also their most characteristic feature.

\section{Sepiolite}

The $515 \mathrm{kt}$ produced in Spain in 1990 were obtained entirely from the Tertiary basins: $453 \mathrm{kt}$ from the Madrid basin. of $\mathrm{kt}$ from the Calatayud basin and $1 \mathrm{kt}$ from the Duero basis. The sepiolite resources in the Madrid basin reach $100 \mathrm{Ml}$. and the estimated production capacity is more than 1 Mtivear. Sepiolite is also present in the attapulgite deposit of Lebrija (El Cuervo mine Guadalquivir basin), with a sepiolite grade of up to $5 \%$ (Fig. 9 ).

In the Madrid basin. sepiolite is quarried at Vicalvaro. Vallecas. Parla and San Blas, to the south of the city of Madrid (Fig. 5). and Yunclillos (prov. Toledo) (Galán \& Castillo. 1984; Ordónez et at. 1992). The sepiolite seams occur at the top of fining-upward sequences of arkosic sandstones. The economic sepiolite seams occur at an intermediate position between the lacustrine deposits of the Middle Unit of the Madrid basin and arkosic sediments derived from granitoid and high-grade metamorphic source areas that outcrop in the northwestern part of the Madrid basin (Fig. 10).

The classic sepiolite deposits of Vallecas-Vicalvaro were exploited three centuries ago to obsain the light rough stone of Madrid buildings, and special tefractory clays. The areal extent of these deposits is almost $6.6 \mathrm{~km}^{2}$, and they consist of two exploitable layers of sepiolite with sharp lateral changes of facies to the neighbouring abundant arkosic sandstones. The thickness of the upper layer, the richest in sepiolite, is up $1010 \mathrm{~m}$, and it is separatcd from the lower sepiolite layer by more than $15 \mathrm{~m}$ of non-economic muddy sandstones. The lower sepiolite layer is 1 to $5 \mathrm{~m}$ thick. A

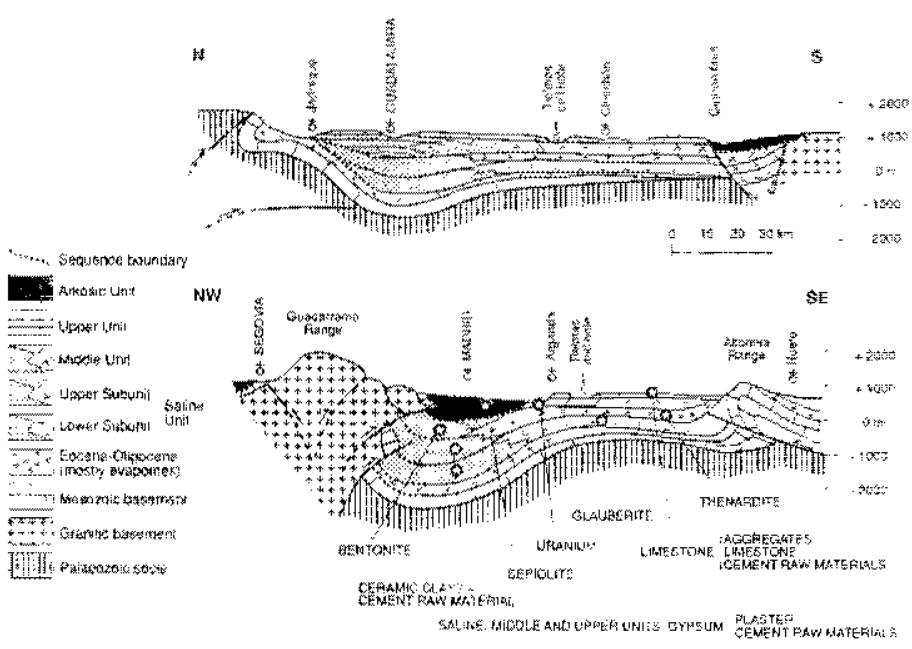

Fig. 10. Sclematic cross-section of the Neogene Madrid basin (adapted from Megias ef al., 1983) showing stratigraphic location of main mined mineral deposits: glauberite, thenardite, sepiolire, bentonite, ceramic clays, Portland cement raw materials, dimension stone (Colmenar limestone) aggregates (crushed limestones), lime raw materials and uranium occurrences.

dassic mammal site (Cerro Almodovar sile) of Midde to Late Aragonian age is locatcd in the muddy marls at the top of the lower sepiolite layer. The sepiolite grade varies between $65 \%$ and more than $95 \%$, being accompanied by smectites guartz, ilite. feldspars and carbonates. This is the world s most important known deposit of sepiolite (Galán \& Castillo. 9841.

The Yuncillos sepiolite deposits extend over $3 \mathrm{~km}^{2}$ and there are two sepiobite-containing layers. The lower sepiolite layer is richer than the unper layer and its thickness is up to $3 \mathrm{~m}$. The upper layer contains smectitc and nodular chert. The location is close to Valiecas and Vicalyaro. In Paracuellos del Jarama least of the city of Madrict there are important reserves of sepiolite probably subeconomic because of the thick cover and its location in an urban area. The seams of the Paracuellos sepiolite deposts are interbedded with burrowed muddy arkosic sandstones and. in places. with reworked sepiolite and paiteosols (Alonso et $u$ t. 1986). The genesis of the Paractellos sepiolite deposits has been reported as edaphic to paludal in a distal aliuvial fan environment (Calvo ot al. 1986). Some uranium vanadates (yuyamunitel have been formed in the edaphic environment. associatcd with dolocretes and with vertebrate remains in the marls (Arribas, 1963). In our opinion, it is possible to define a sepiolite bet along the Macidid arkosic trench, elongated from NW to SE from Yunclillos to Paracuellos des Jarama. with many sepioite occurences as at north $\mathbf{L}$ a Sagra, north Esquivias. Parla. North Getafe, ete.

In the Calatayud basin, sepiolite marls were exploited a few years age in the Isabel mine (Orera). The annual production of this mine. as we have pointed out before, was up to $61 \mathrm{kt}$ in 1990 (IT GE. 1992). The sepiolite deposits of the Calatayud basin are interpreted as lacustrine deposits in a brackish shallow lacustrine environment. Arauzo et al. (1989) describe the mineralogical paragenesis: dolomite. illite. smectite and quartz. with minor amounts of calcite. 


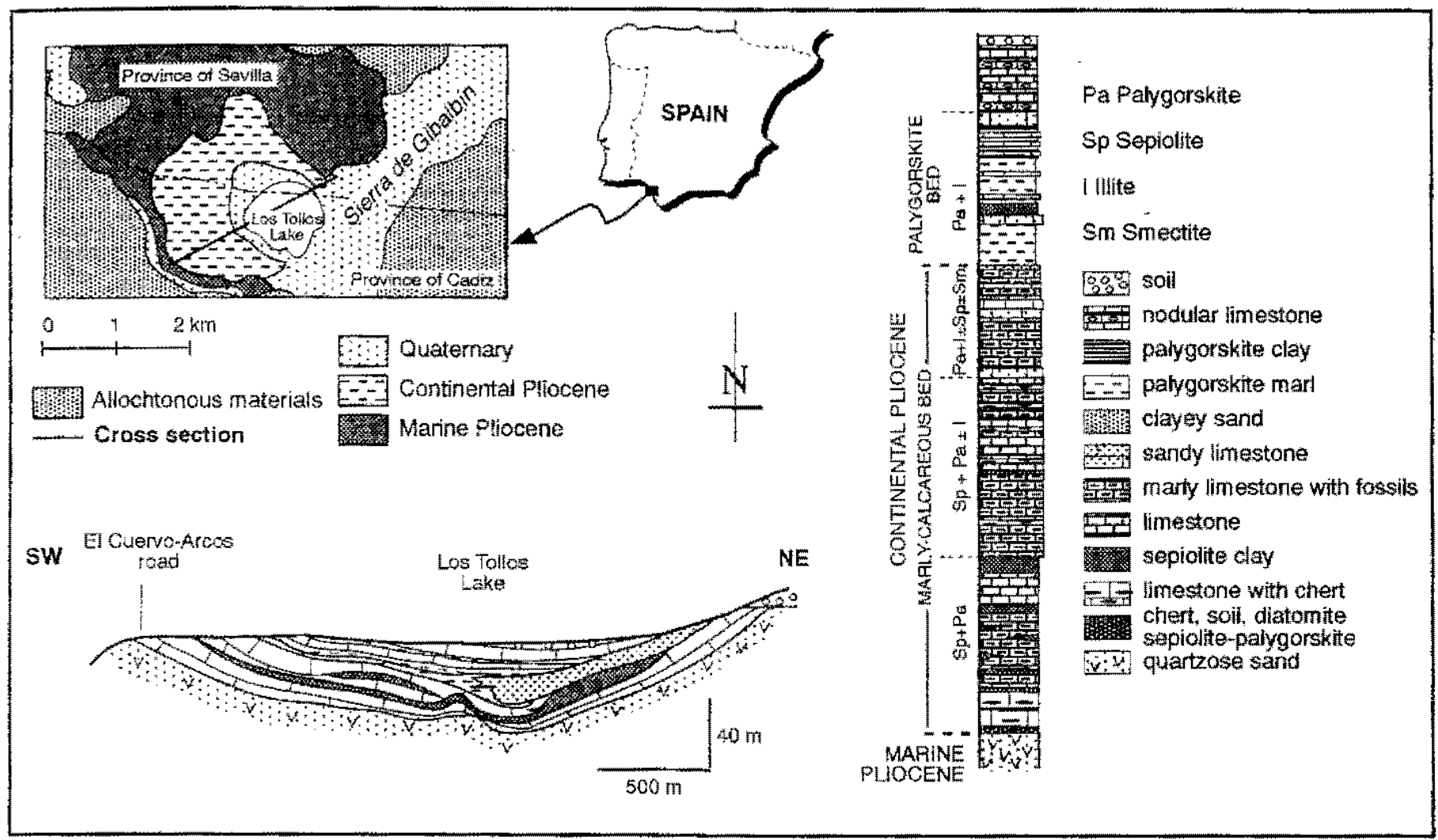

Fig. 11. Geological location of El Cuervo attapolgite mine, cross-section and detaiked stratigraphic section. After Galán \& Ferrero (1982).

faldspars, chlorite and katinite in the Mara area, and sepiolite alternating with smectites in the Orera area. Early diagenetic vadose to edaphic processes of carbonate-siliceous (due to diatoms and or detrital clays) sediments may explain the genesis of the sepiolite marls. Other occurrences of sepiolite maris south of Guadalajara (Madrid basin) and Cuestas Facies (Duero basin) may be interpreted in similat way.

\section{Altupulgite}

The 1990 Spanish attapulgite production was $54 \mathrm{kt}$. The most important production comes from the El Cuervo attapulgite mine (Sevilla and Cádiz provinces) and only $4 \mathrm{kt}$ was from the Torrejon el Rubio attapulgite daposit (Fig. 9).

The El Cuervo mine is located in a Pliocene to (?)Quaternary lacustrine deposit. (Galán \& Ferrero, 1982) (Fig. 11). Two main units are distinguished; a lower marly layer and an upper palygorskitic (attapulgitic) layer. The thickness of the attapulgite layer varies from 3 to $30 \mathrm{~m}$ with an attapulgite grade of between 35 and $75 \%$ and with minor sepiolite $(0-30 \%)$ and calcite. It includes some Cossiliferous limestone beds interbedded in the attaputgite seam. The estimated resources are up to $30 \mathrm{Mt}$.

The Torrejon el Rubio deposit is located in the small Tertiary fauh basin of Torrejón ej Rubio (Gatan \& Castillo, 1984). The source area and the basement of the basin are deeply weathered slates. The lowest basin fill is composed of weathered slate material and this layer is overlain by a terrigenous-muddy bed with a thickness that varies from 6 to $50 \mathrm{~m}$. On top of this bed $(0.5-4 \mathrm{~m})$ an attapulgite grade of up to 70 o can be measured. Paragenesis of the attapulgite deposit is. in addition to attapulgite. palygorskite ilite \pm smectite (saponites) 1 chlorites - sepiolite \pm quart $z$ feldspars and dolomite. The genesis of the attapulgite deposits appears to be a result of a magnesium-rich weathering process that affected clayey, probably illite-rich, sediments (Fig. 12).

Some attapulgite occurrences have been described in the lacustrine sequences of the Tertiary Duero basin: Garcia del Cura \& Lopez Aguayo (1974); Pozo \& Leguey (1985); in Sacramenia: Martin Pozas et al. (1983), and in Bercimuel: Suárez al. (1989) and Suzrez et al. (1991). Other less-important attapulgite occurrences have been described in which the mineral forms a cement of the proximal cetrital facies of the Madrid and Duero basins (Ordónez et al., 1977; Megías et al., 1982; Leguey et al., 1984a and b). The paragenesis of these attapulgite occurrences includes palygorskite \pm cristobalite \pm dolomite, interpreted as late diagenetic cement of the arkosic sandistones.

\section{Bentonites}

The 1990 Spanish production of Ca-bentonite was $151 \mathrm{kt}$, and this came from two districts: Cabo de Gata (Almeria province) and Villaluenga (Toledo province).

The Cabo de Gata district deposits are associated with the 


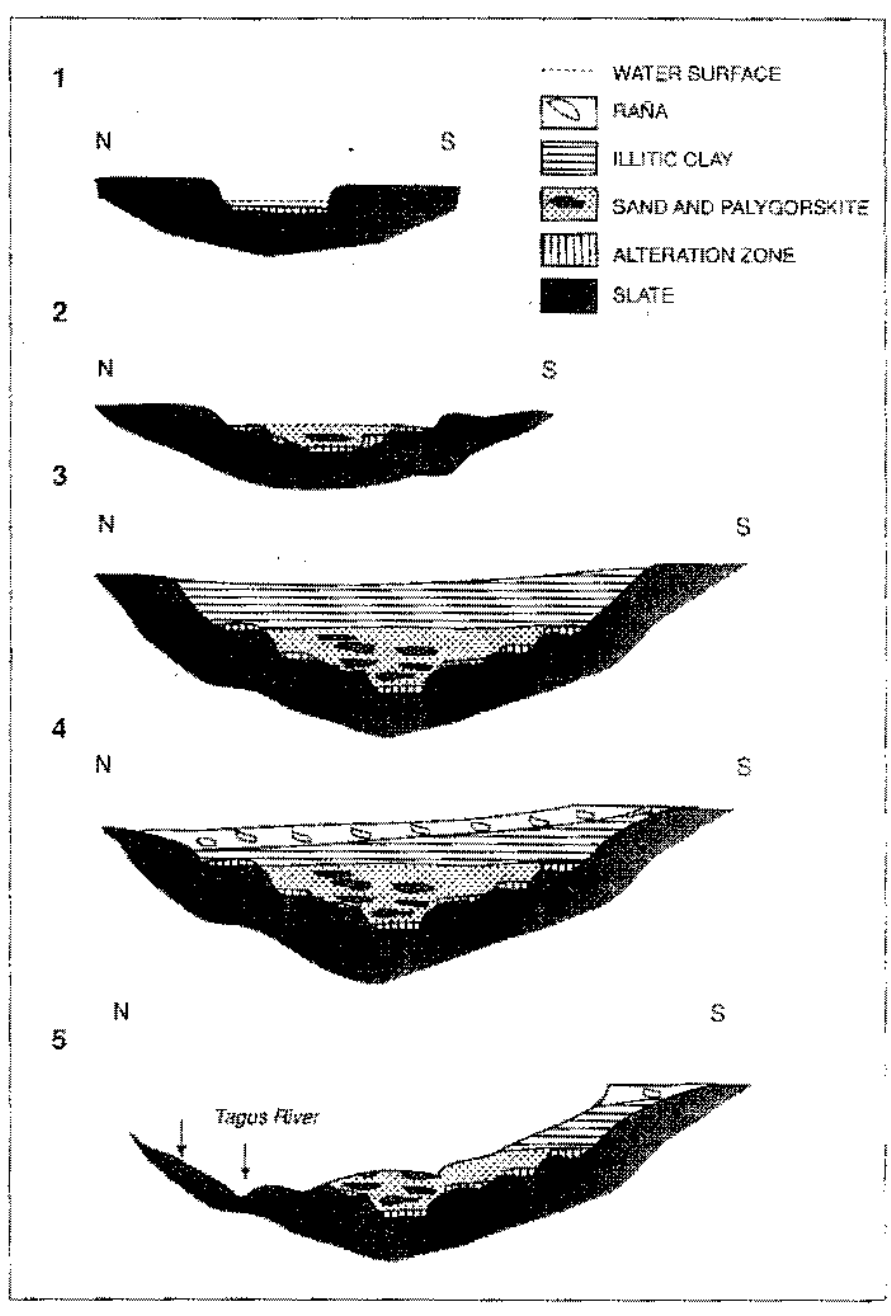

Fig. 12. Schematic interpretation of Torrejón el Rubio attapulgite deposit from the 1 , weathering of substrate; 2 , clayey sand sedimentation and early diagenetic (vadose) magnesium-rich attapulgite, probably related to low sedimentation; 3, silting up sedimentation; 4, alluvial fan ('raña) deposits; 5 , fluvial network trenching, After Galăn \& Castillo (1984).

Neogene calc-alkaline volcanism of SE Spain, with an age of the volcanism varying between 8 and $17 \mathrm{Ma}$.

The main bentonite mine is in the La Serrata-Los Trancos deposit, and the production of this mine is up to $100 \mathrm{kt} / \mathrm{year}$. The proven aserves are estimated as $3.5 \mathrm{Mt}$ (1. Teodoro, pers, comm mun.). According to Doval (1992) the average purity of the smectites is up to $98 \%$. The genesis of these bentonite deposits is low temperature (about $40-70^{\circ} \mathrm{C}$ ) hydrothermal alteration of volcanic rocks (Leone et al., 1983): about $70^{\circ} \mathrm{C}$ in the Sierra de Gata and about $40^{\circ} \mathrm{C}$ in the Serreta de Nijar. The mineralogical paragenesis of the Serreta de Nijar deposits has been deseribed by Caballero af (1983) as formed mainly of smectites, the only phyllosilicate present in the fine fractions belonging to the montmorillonitebeidellite-nontronite series, along with jarosite, pyrolusite and alpha-trydimite (probably neoformed) and quartz, plagioclase and potassium feldspars; inherited minerals from the parent rocks; the parent rocks are rhyolites, dacites and trachytes. The exchange cation capacity is $\mathrm{Na}^{+}>\mathrm{Mg}^{2+}>\mathrm{Ca}^{2+}>\mathrm{K}^{+}$, and the chemical composition of the bentonite displays wide variations even within the same deposit. The most important bentonite deposits at Serrota de Nijar are closely related to N5OE striking fissures and commonly display vein-fill features.

The bentonites of the South Cabo de Gata zone consist of smectite, jarosite, zeolite and trydimite, as neoformed minerals, and of plagioclase, potassium feldspar, amphiboles and micas as minerais inherited from the parent materials (Caballero et $a i_{\mathrm{x}}$ 1985).

In addition to this volcanogenic interpretation of these bentonite deposits. F. Ferrero (1984) has pointed out the probable infuence of halmyrolytic processes in the genesis of some of the blanket bentonite deposits. The geochenical data seem to exclude a marine origin sor the alteration solution, and favour the idea that the sohtions resulted from a system of meteoric waters heated by a geothernal cycle (Gaballero $e t a t_{x}, 1985$ ).

The Villaluenga district (Toledo province) is located in the Middle Unit of the Ncogene Madrid basin (Middle Aragonian). It occurs in a transitional zone between the outer marginal facies and imer chemical tacies of the lacustrine sequences. These bentonite deposits usualiy occur in laterally continuous levels $0.4-2 \mathrm{~m}$ thick. Commonly, the bentonites are intercalated in the lacusine sequences with distal deltaic micaceous sands and dolomitic carbom nates, some chert nodules and other mudstones. The mineralogy of the bentonites is essentially Mg-rich smectites, mostly stevensite and saponite (Calan et al. 1986; Pozo of al. 1991), and their potential as backfilling and sealing material in high-level radioac tive waste disposal is very interesting (Cuevas. 1992; Cuevas e: ai. 1993). The reserves of the Madrid basin are probably up to $10 \mathrm{Mt}$, located in a closed stratigraphic position from Cerro del Aguila (Villahenga) to the southern part of the city of Madrid. markedy paraliel to the sepiolite belt. The reserves of the mined deposits at Cerro del Aguila (Villalucnga) are up to 0.7 M:

Some 'pink clays' formed by interstratifed kcrolie. most probably stevensite with interlayered kerolite related to the bentonits deposits, are found (Martin de Vidales at. 1989. 1991). These 'pink clays' have been used as an oil discolourant. Pink clay layers areassociated with dessication levels developed over bentonitic clay beds (green colour). The possible resources of pink clays in the Madrid basin are up to $2 \mathrm{ML}$.

\section{Ceramic clays}

Aimost all the marginal and basal formations of the continental Tertiary basins of the lberiun Peninsula contain clay sediments that are being used as ceramic raw matcrials. In this facies there are large volumes of material that are potential sources of ceramic clays. They have a variable mineralogical composition, but ilite is generally the most abundant phylosilicate mineral. Cotnm mercial interest in these clay-rich sediments depends on the physical properties of the crude materials: plasticity, drymg capacity with. out shrinkage, extrusionability, fring temperature, and, after firing, degree of efforescence, permeability and compressive strength, 
ctc. However, the distance from the location of the clay-rich sediment deposits to the potential consumption centres may be the most important economic factor, because haulage costs may yuick!y make the price prohibitive.

Recently, Gonzálcz Diaz (1992) has reviewed Spanish ceramic clays. The most important ceramic-clay production areas ate Woated in the Cradalquivir basin (Bailén) and in Madrid basin (La Sagra-Akxala de Henares) (Fig, 9).

The ceramic raw materials mined in the Batch area are of Miocene atge, and have an average mineralogical composition of $20 \%$ quartz, 12\%, foldspars. $25 \%$ calcite and $54 \%$ phylosilicate. mainly illite and smectite (González ef al. 1986 ).

The ceramic mw materials exploited in La Sagra (Toledo prolince) and Aloala de Henares (Madrid provincel are located in the Lower Lnit of the Neogene Madrid basin (Lower Aragonian). The average content of illitic clays is up to $50 \%$ I Menduina. 1988: Garcia et at.. 1990). Resources amount to $500 \mathrm{Mt}$. These clay-rich sedments are used to add a top-quality silicate component to Portund cement (Garcia Calleja et at. 1991). The potteries producLion at La Sagra rewches $2.5 \mathrm{Mt}$ tar year.

Clays from the basal Unit (Tierta de Campos) of the Ducro basin in the area near Valladolid are also exploted for use as ceramic raw materiats.

\section{Diatomites}

Spanish diatomite production during 1990 was $107 \mathrm{kt}$ lower than the 1986 production. Spanish diatomite deposirs occur in Noogene formations in the souhern part of Spain in the Gradalquivir Basin (Porcuna and Martos), the Prebetic intramon. tane basins and the lnternat Betics intramontane Late Miocene hasins (Sorbas. Vera, and Nijar in Almeria and Mutcia provinces) (Calvo. 1984: Recueiro et ul. 1993).

The Probetic area supplies more than 90\% of the total Spanish ditamite production. The Hellin diatomite district exterds over more than $\$ 00 \mathrm{~km}^{2}$. and the diatomite occurs here in several bitsins that were cither separated or episodically intercomected: the Cenajo Busin. Camarillas Basin. Calderones Basin. Elche de la Sierra Basin and Hijar Basin (see Table 5). These five intamonane basins outcrop along the Mundo and Segura viver valleys. A schematic stratigraphic column for these basins has been proposed recently by Elizaga \& Calvo (1988) (Fig. 13). Sedimentological and isotope data have been reviewed recently by Bellanca $t$ t al (1989). The diaromacous sediments are close to Facies E just above a 30 $50 \mathrm{~m}$ thick megaslump. These meguslumps are associated with volcanim and or a probably tectonic ractivation of the basins. The K A A age of the volcanism measured in the Monegrillo is up to 5 Ma (Beilon tal. 1981). The maguslump-level offers the best marker in prospecting for diatomite in the district Regueiro et al. 19931 .

Ten per cent of Spanish diatomite production is from the Nijar Basin (Almeria); these diatomaceous sediments are located in mmthick laminated shates formed by couplets of dark organic-rich oil shale and clear diatomite-rich laminae. The age of the deposits
Table 5. Kexperves and resuarces th hatomite deposits in the Hellin

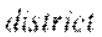

\begin{tabular}{|c|c|c|c|c|c|}
\hline & Conajo & Camarillas & Calderones & Elche & Hijar \\
\hline $\mathrm{rl}$ & 7.5 & $\cdots$ & - & - & - \\
\hline rII & 18.7 & 39 & - & 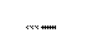 & - \\
\hline r III & - & $\ldots . .-$ & - & - & 5 \\
\hline R I & 152 & 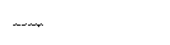 & - & - & - \\
\hline R II & 133 & 12 & - & 337 & - \\
\hline R III & 8.8 & - & 34 & - & سمس \\
\hline
\end{tabular}

Voles.

Reserves (n) and identifed resources $(R)$ in $M t$ for the different basins. $1 \mathrm{SiO}_{2}<30 \%$. $1130 \%<\mathrm{SiO}_{2}<70 \%: 111 \mathrm{SiO}_{2}>70 \%$. Sumet Adapied from Regueiro at al. (1993).

spans the interva from Late Tortonian to Early Messinian (Reyes (') al., 1984).

Diatomaccous sediment occurrences, sometimes mines, have been cited in the Guadalquivir Basin. for example at Sanlúcar de Barrameda, Porcana, and Martos. Earlier in this chapter we have cited the diatomaceous sediments in the El Cuervo attapulgite deposit. Other occurrences have been cited in the Madrid basin (Cavo et at. 1988), and in the Cerdanya basin. In this last occurrence, dated as Midde-Late Miocene. Anadón et al. (1989) have described a diatomaceous mudstone facies with fine lamination.

\section{Dimension (building) stone}

Spain plays a very important role in the world stone industry. The natural stone production of Spain accounts for $13.2 \%$ of the worid total (Lombardero \& Regueiro. 1992).

Some Tertiary limestones of the Inner Prebetic Units have great purity and soundness. are easily polished and may be considered as 'commercial murbles or marbles of type $C$, according to the Marble Institute of Anerict (MIA). The quarries are grouped mainly in three areas: Coto Pinoso and Peña de Zafra in Alicante province and Sierra de la Puerta in Murcia province. The most famous quarries are located in Colo Pinoso, where the 'Crema Marfil' marbie is obtained; the 1989 production of blocks as up to $10^{5} \mathrm{~m}^{3}$, ind the proven reserves are $7 \times 10^{3} \mathrm{~m}^{3}$. From a petrographic point of view the Coto Pinoso limestone may be classified as a biosparitebiomicrite (Llopis \& López Jimeno. 1991).

The "Colmenar de Oreja Limestone" has been obtained from the Upper Unit of the Madrid basin (Fig. 10), and it has been used since the eightaenth century in the construction of buildings and monuments in Madrio (Dapenai et al. 1988). According to the ASTM American Society for Tesing of Materials) Standard C-568-79, Colmenar limestone is among the most suitable for use for the outside of buildings (Danena of al. 1988). Colmenar limestones are paludine lacustrine biosparites with less than $2.45 \%$ porosiry. At present, Colmenar limestones and other similar limestones of the Upper Tertary Unit of Madrid are intensively used as crushed 


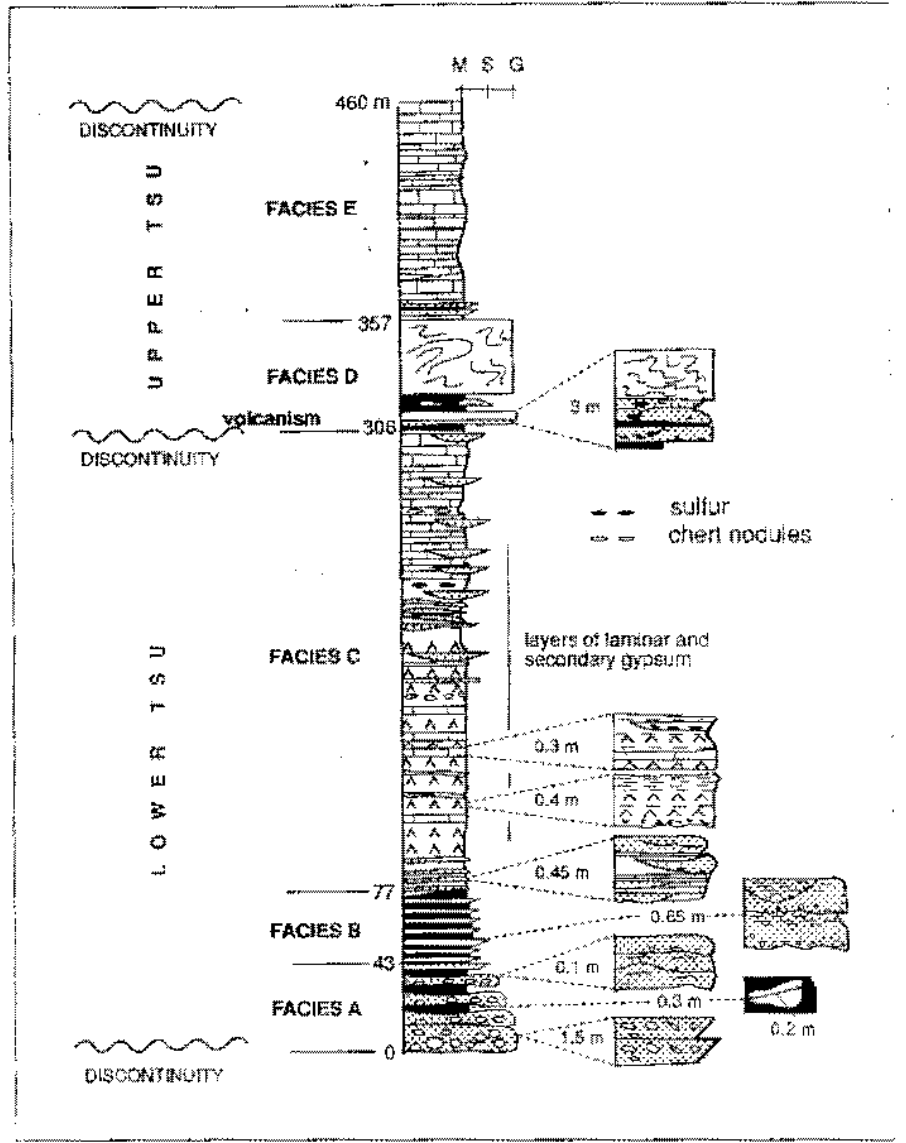

Fig. 13. Schematic stratigraphic section of Cenajo basin: $A$, conglomeratic basal beels; $B$, sandy layers in laminated oil shales; $C$, this subunit consists of alternations of laminated detrital carbonate and gypsum; $D$. megaslump subunit probably related to eruptive voleanisu $(5.7 \pm 0.3 \mathrm{Ma}$ after Bellón et al., 1981); E, diatomaceoss sediments. After Elizaga \& Calfo (1988). "TSE" refers to Tecto sedimentary unit (chapter G1).

aggregate raw materials, cement raw materials, and lime raw materials ( $>98 \% \mathrm{CaCO}_{3}$ ) and filjers / Garcia Calleja. 1991; Garcia Callejá et al., 1991; Garcia del Cura et al 1993 ).

\section{References}

Alvarez Ramis, C., Femandez Marrón. M.T., Garcia del Cura, M.A. and Ordonez, S. (1989). Preliminary data and palevecologicalcharacteristics of the Saline Unit fiora from the Tertiary Maduid basin. Abstracts II European Pateobotatical Conf Madrid: 19.

Anadón, P., Cabrera, L., Juliá. R., Roca, E, and Rosell L. (1984). Lacustrine oil-shale basins in Tertiary grabens from NE Spain (Western European rift system). Palazogengz, pulacocimatol. Palaeoecot. 70: 7-28.

Arauzo Perez, M.. González López, I.M. and López Aguayo, F. (1984). Primeros datos sobre la mineralogia y genesis del yacimiento de sepiolita de Mara (Prov. de Zaragoza). Bol. Soc Esp. Minterci.. 12: $320-340$.

Artibas, A. (1963). Mineralogia y metalogenia de los yacimientos espanofes de uranio: Paracuellos del Jarama (Madrid) Bol. R. Sat: Espat nola Hist. Nat., 61:63-65.

Arribas Rosado. A (1992). Los yacimientos de oro del sureste peninsular.
In Garcia Guinea, J, and Martínez Frias. J. (eds, Recurvos Minerales de España, Textos Univetsitatios, 15. C.S.1.C.: $875-890$

Bacelar, J. Alonso, M., Kaiser, C., Sinchez, M. Cabrera, L., Ferrus, B. Sátz, A and Santanach, P. (1991). Relaciones tectorica-sedim mentación de la Cuenca Cenozoica de As Pontes (A Coruna). Congreso del Grupa Español del Terciario: 25-27.

Bellanea, A. Calvo, J.P., Censi, P., Elizaga, E. \& Neri, R. (1989). Evolution of iacustrine diatomite carbonate cycles of Miocene age, southeastern Spain: petrology and isotope geochemistry., . Sed. Peirol., 59: 45-52.

Bellon, H. Bizon, G., Calvo, 1.P. Elizaga, E, Gaudant, 3. and López, N. (1981). Le volcan de Cerro de Monegrillo (province de Murcia): age radiometrique et correlations avec les sediments Neogènes du Bassin de Hellín, C. A Acad. Sci. Paris, 2eme série, 11: 1035-1038.

Cabal!ero. E. Fernández Porto, M.I. Linares J. and Reyes, E. (1983). Las bentonitas dela Serrata de Nijar (Almeria). Mineralogia, yeoquimica y mineralogeresis. Estudios Geol. 39: 121 140.

Caballero, E, Reyes, E, Lnares, J. and Huertas, J, (1985). Hydrothermal solutions related to bentonite genesis. Cabo de Gata region. Ameria, SE Spain. Mineral. Petrograph. Acta. 29A: 187 . 196.

Caballero. E.. Reyes, E., Yusta, A., Huertas. F. anú Linares, J. (1985). Las bentonitas de la zena sur de Cabo de Gata (Almeria). Geogún-

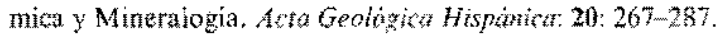

Cabrera. Li and Sazz A (1987), Coaldeposition in carbonate-rich shallow lacustrine systems the Calât and Mequitenza seouences (Oligóncene. Eastern Ebro basin, NE Spant. J. Geot. Sok, Lomo. 144: $451-461$

Calvo. J.P. (1984). Los yacimientos españoles de diatomitas. In Leguey. S., Menduna. J. and Ordonez. S. (eds.) Schunds Curso de Rorks industriales: $330-34 \%$.

Cako, J.P. Pozo, M. and Serwant Vijdar, S. (1988). Lacustrine diatomite deposits in the Madrid Busin ICentral Spain. Groguceth, 4: $14-17$.

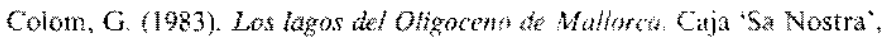
Palma de Mallorca, $160 \mathrm{pp}$.

Crespo Zamorazo, A. (1988a). Primeras notas sobre los yacimientos cobaltíferos en el Plioceno del Campo de Calatrava (Cindad Real). Bol. Sor. Espontala Minerat. 11: 144 15 .

Crespo Zamorano, A. (1988b). Depositos de mannanesos cohaltiferos en

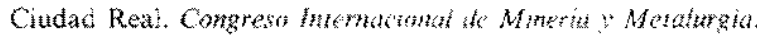
Oviedo.

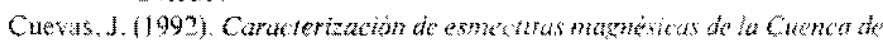
Madiat como materiales de sellade. Publicacion Tonica no ot 92. ENRESA, Madrid, $188 \mathrm{pp}$.

Cecvas.J., Pelayo, M. Rivas P. and Legues. S. (199.3) Characterization of $\mathrm{Mg}-\mathrm{clays}$ from the Neogene of the Madrd Basin and their potental as backfthing and sexting nuteriat in high level radiodetive waste disposal. Anpl. Clar \$6. 7: 199 . 214.

Dapema. E. Ordoncz. S. and Garcia del Cura. M.A. (1982). Sidy of limcstone rock used in the construction of pdaces in Madrit during the 18 th and 19 th centutios. In P.G. Marnos and $G . C$.

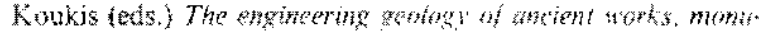
ments and historicul sites, Balkema. Rouerdam: $683-690$

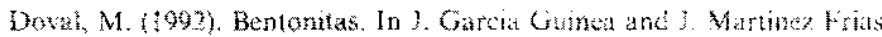

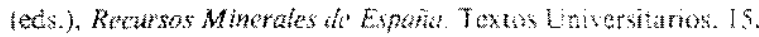
C.S.I.C. $45-69$

Elizaza, E. and Calvo, J.P. (1988). Evolucion sedimentaria de las cuencas

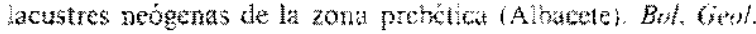
Mineral, 99: 837-846.

Fernandez Nisto, C and Galán, E. (1979). Mineralogia do los depositos de

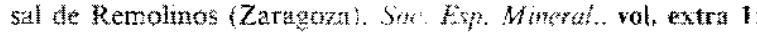
$51-65$.

Ferrero. F. (1984). Las depositos de sepholita bontonta y artapulgita on Espata. In Leguey, S. Menduinta. J. and Ordónes S, (eds.) 
Segundo ('urso de Rocas Industriales. Fundación Universidad Empresa, Madrid: 126-135.

(jalán. E. and Castillo. A. (1984). Sepiolite-palygorskite in Spanish Tertiary basins: genetical patterns in continental environments. In Singer and (jalan teds.), Palygorskite-Sepiolite: occurrences, genesis and uses. Elsevier: 87124.

Galán. E. and Ferrero. A. (I 982). Palygorskite-sepiolite clays of Lebrija, Southern Spain. Clay. Clay Mineral. 30: 191-199.

Galan. E., Brell, J.M.. La Iglesia, A. and Robertson, R.H.S. (1975). The Cáceres palygorskite deposit. Spain. In Bailey, S. (ed.). Proc. Int. Cla1 Conf. iféxico Applied Publ. Ltd. Illinois: $81-94$.

Garcia, E., Brell, J.M., Doval, M. and Navarro, J.V. (1990), Caracterización nineralógica $y$ estratigratia de las formaciones neogenas del borde Sur de la Cuenca del Tajo (Comarca de La Sagra). Bol. (ieol. Min.. 101: $945-956$.

Garcia Caileja. M.A. (1991). Estudio petrológico y geoquimico de las materias primas de la Cuenca de Madrid para su uso en lá industria cementera. PhD Thesis. U.C.M. Madrid. 463 pp.

Garcia Calleja. M.A. Soriano. J. and Ordónez, S. (1991). Materias primas para la fabricación de clinker de cemento Portland en el area de Madrid. HV Congreso de Geoquímica de España: 493-506.

Garcia del Cura, M.A. (1979). Las sales sódicas, calcosódicas y magnésicas de la Cuenca del Tajo. Serie Universitaria. 109. Fundación Juan March. Madrid. 39 pp.

Garciáa del Cura. M.A. and López Aguayo. F. (1974). Estudio mineralógico de las facies detritico -. calcáreas del Terciario de la Zona CentroOriental de la Cuenca del Duero (Aranda de Duerol. Estud. Geol.. 30: $503 \cdot 513$

García del Cura. M.A.. Ordonez. S. and Lopez Aguayo, F. (1979). Estudio petrológico de la Unidad Salina de la Cuenca del Tajo. Estud. Geol. 35. 325-339.

García del Cura, M.A.. Ordóñez. S. \& González. J.A. (1991). Los carbonatos biogénicos de los episodios terminales del relleno Neógeno de la Cuenca de Madrid. Comunicaciones I Congreso del Grupo Español del Terciario: 136-139.

Garcia del Cura, M.A.. Ordónez. S. and Sánchez Moral, S. (1992). Lin yacimiento de gla luberita en facies evaporiticas marginales: Mina Consuelo (San Martin de la Vega - Madrid). Actas III Congreso Geologico de España y VIII Congreso Latinoamericano de Geologia, 3: 372-377.

García del Cura, M.A., Ordóñez, S., González, J.A., Dapena, E.. Cañaveras, J.C., Díaz Alvarez, M.C.. García Calleja, M.A., Galindo, E.. Martínez Alfaro, P.E., Calvo, J.P., La Iglesia, A. and Sanz. E. (1993). Las canteras de calizas de los interfluvios de los ríos Jarama-Tajuña Tajo en la Comunidad de Madrid: valoración de recursos, impacto ambiental y propuestas de restauracion. 84 pp. + maps (unpublished).

García Guinea, J. and Martinez Frias. J. (eds.) (1992). Recursos minerales de España. Textos Universitarios, 15. C.S.I.C. Madrid, 1448 pp.

García Veigas, J., Fernández Nieto, C. and Orti, F. (1991). Nota sobre la mineralogía y petrología de la Formación Zaragoza en el sondeo Purasal. Bol. Soc. Española Mineral. 14-1: 82 83.

González Diez, I. (1992). Arcillas comunes. In Garcia Guinea, J. and Martinez Frías, J. (eds.) Recursos Mineral. España, C.S.I.C.: $95-112$.

González, I.. Renedo, E. and Galan, E. (1986). Clay materials for structural clay products from the Bailen area Southern Spain. Uppsala Symposium Clay Minerals-Modern Society, 1985. Nordic Society for Clay Minerals: 77-90.

Gorch, R., De Las Heras, F.X., Grimalt, J., Albaiges, J., Sáez, A. and Cabrera, Ll. (1992). Biomarcadores en los lignitos lacustres oligocénicos de la Cuenca del Ebro (Calaf, Mequinenza). III Congreso Geológico de España, Simp. I: 88-97.

Griffiths, J. (1991). Spain's minerals: mixed fortunes. Industrial Minerals, 285, June: 23-47.
IGME (1985). Actualización del inventario de recursos nacionales de carbón. MIE Madrid: $217 \mathrm{pp}$.

ITGE (1991). Panorama Minero 1989. MIE, Madrid, 428 pp.

ITGE (1992). Panorama Minero 1990. MIE, Madrid. 719 pp.

Leguey. S.. Martin de Vidales, J. and Casas, J. (1984a). Diagenetic palygorskite in marginal continental detrital deposits located in the South of the Tertiary Duero basin (Segovia). In Singer and Galán (eds.) Palygorskite-Sepiolite: occurrences, genesis and uses. Developments in Sedimentology, 37. Elsevier: 149-156.

Leguey, S.. Menduiña, J. and Ordóñez, S. (1984b). Segundo Curso de Rocas Industriales. Apuntes Universidad Empresa, Madrid, 494 pp.

Lcone, G.. Reyes, E., Cortecci, G., Pochini, A. and Linares, J. (1983). Genesis of bentonites from Cabo de Gata. Almeria, Spain: a stable isotope study. Clay Mineral. 18: 227-238.

Llopis, L and López-Jimeno, C. (1991). Crema Márfil, un mármol con futuro. Canteras y Explotaciones, March: 50-58.

Llopis, L.. López-Jimeno, C. and Mazadiego, L.F. (1992). Rocas ornamentales de Alicante. Canteras y Explotaciones, January: 103-113.

Lombardero. M. and Regueiro, M. (1992). Spanish natural stone: cladding the world. Industrial Minerals, 300: 81-97.

Mañana. R. (1992). A synthetic overview of the Spanish mining industry. AITEMIN. 15 pp.

Manteca. J.I. and Ovejero, G. (1992). Los yacimientos $\mathrm{Zn}, \mathrm{Pb}, \mathrm{Ag}-\mathrm{Fe}$ del distrito minero de la Unión-Cartagena, Bética Oriental. In J. Garcia Guinea and J. Martínez Frias (eds.) Recursos Minerales de España. C.S.I.C.: 1085-1102.

Martin. J.M.. Ortega Huertas, M. and Torres Ruiz, J. (1984). Genesis and evolution of strontium deposits of the Granada basin (Southeastern Spain): evidence of diagenetic replacement of a stromatolite belt. Sediment. Geol. 39: 281-298.

Martin Calvo. M. (1973). Sobre la petrogénesis de algunas litofacies españolas con fases urano-orgánicas. PhD Thesis. U.C.M. Madrid: $306 \mathrm{pp}$.

Martín Delgado, J. (1975). Pasado, presente y futuro de la investigación uranifera en España. Energia Nuclear, 19: 321-329.

Martín Pozas, J.M., Martín Vivaldi, J. and Sanchez Camazano, M. (1983). El yacimiento de sepiolita-palygorskita de Sacramenia, Segovia. Bol. Geol. Min., 94: 112-120.

Martín de Vidales, J.L., Pozo, M. and Leguey, S. (1989). Kerolite-stevensite mixed layers from Neogene Madrid Basin. Genetic implications (abstract). International Clay Conference, Strasbourg: 246 pp.

Martín de Vidales, J.L., Pozo, M. Alia, J.M., Garcia Navarro, F. and Rull, F. (1991). Kerolite-stevensite mixed-layers from the Madrid Basin, Central Spain. Clay Minerals, 26: 329-342.

Megias, A.G.. Leguey, S. and Ordóñez, S. (1982). Interpretación tectosedimentaria de la génesis de fibrosos de la arcilla en series detríticas continentales (Cuencas de Madrid y del Duero) España. $5^{\circ}$ Congreso Latinoamericano de Geologia, Argentina, Actas II: $427-439$.

Megias, A.G., Ordóñez, S. and Calvo, J.P. (1983). Nuevas aportaciones al conocimiento geológico de la Cuenca de Madrid. Rev. Material Procesos Geol., 1: 163-191.

Menduiña, J. (1988). Geología y significado económico de las arcillas cerámicas de la Cuenca de Madrid. PhD Thesis. U.C.M. Madrid. 305 pp.

Menduiña, J.. Ordóñez, S. and Garcia del Cura, M.A. (I984). Geología del yacimiento de glauberita de Cereza del Río Tirón (Provincia de Burgos). Bol. Geol. Mineral., 95: 33-51.

Meseguer Pardo, J. (1924). Estudio de los yacimientos de azufre en las provincias de Albacete y Murcia. Bol. Inst. Geol. 45: 1-84.

Michell, B. (1979). Geography and resource analysis. Longman, London, 399 pp.

Ordóñez. S., Brell, J.M. Calvo, J.P and Lopez Aguayo, F. (1977). Contribución al conocimiento mineralógico del borde $\mathrm{SW}$ de la Cuenca del Tajo (Toledo-San Martin de Pusa). Estud. Geol, 33: 467-472. 
Ordóñez, S. and Garcia del Cura. M.A. (1992). El sulfato sódico natural en España: Las sales sódicas de la Cuenca de Madrid. In I. Garcia Guinea and J. Martinez Frías (eds.), Recursos Minerales de España. Textos Universitarios, 15, C.S.I.C.: $12229 \cdot 1250$.

Ordóñez, S. and Garcia del Cura, M.A. (1994). Sodium-calcium sulfate salt deposition and diagenesis in Tertiary saline lakes: Madrid Basin (Spain). Spec. Publ. SEPM, 150: 229-238.

Ordóñez, S., López Aguayo, F. and García del Cura. M.A. (1980). Contribución al conocimiento sedimentológico del Sector Centro-Oriental de la Cuenca del Duero (Sector Roa-Baltanás). Estud. Geol. 36: 361-369.

Ordóñez, S., Menduiña, J. and García del Cura, M.A. (1982). El sultato sódico natural en España. Tecniterrae, 46: 16-33

Ordóñez, S., Fontes, J.Ch. and García del Cura, M.A. (1983). Contribución al conocimiento de la sedimentogenesis evaporitica de las cuencas neógenas de Madrid y del Duero. en base a datos de isótopos estables $\left({ }^{13} \mathrm{C},{ }^{18} \mathrm{O}\right.$ y $\left.{ }^{34} \mathrm{~S}\right)$. Com. $X$ Cong. Nac. Sedimentologia. Menorca: $49-52$.

Ortega Huertas, M. (1992). Yacimientos de estroncio en España: geologia e interés económico. In J. García Guinea and J. Martinez Frias (eds.). Recursos Minerales de España. Textos Lniversitarios. 15 , C.S.I.C., 429-438.

Ortí, F. (1990). Observaciones sobre la formación Zaragoza y unidades evaporitcas adyacentes (Mioceno Continental). In $\dot{F}$. Orti and J.H. Salvany (eds.) Formaciones evaporiticas de la Cuenca del Ebro y cadenas perifericas, $y$ de la zona de Levante. Universidad de Barcelona: 117-119.

Orti, F. and Pueyo. J.J. (1977). Asociación halita bandeada-anhidrita nodular del yacimiento de Remolinos. Zaragoza (sector central de la Cuenca del Ebro). Nota petrogenética. Rev. Inst. Inw. Geol. Dip. Prov. Barcelona, 32: 167-202.

Orti, F. and Salvany, J.M. (eds.) (1990). Formaciones evaporiticas de la Cuenca del Ebro y cadenas perifericas, y de la zona de Levante. Universidad de Barcelona. $306 \mathrm{pp}$.

Ortí, F., Pueyo, J.J. and San Miguel, A. (1979). Petrogénesis del yacimiento de sales sódicas de Villarrubia de Santiago. Toledo (Terciario continental de la Cuenca del Tajo). Bol. Geol. Min. 90: $347 \ldots 373$.

Pérez García, L.C. and Sánchez-Palencia, F.J. (1985). Los sedimentos auriferos en la Antiguedad. Investigación 1 Ciencia, 104: 6475.

Pérez Garcia, L.C. and Sánchez-Palencia, F.J. (1992). Los yacimientos de oro de Las Médulas de Carucedo (León). In J. Garcia (juineá and J. Martínez Frías (eds.). Recursos Minerales de Espania. Textos Universitarios, 15. C.S.I.C.: 862-873.

Porter, D.H. and Alvarez Morán, B. (1992). Mineraiizaciones de oro del Noroeste de España. In J. Garcia Guinea and J. Martinez Frias (eds.). Recursos Minerales de España. Textos Universitarios. 15. C.S.I.C.: $849-860$.

Pozo, M. and Leguey, S. (1985). Distribution of clay minerals in central facies, Duero Basin, Valladolid province. Spain. Mineral. Petror graph. Acta: 29-A: 344-345.

Pozo, M., Cuevas, J., Moreno, A., Redondo, R. and Leguey, S. (1991). Caracterización de arcillas magnesicas bentoniticas en la zona de Yuncos (Toledo). Bol. Geol. Min. 102: 893-904.

Pueyo, J.J. (1975). Estudio petrológico y geoquímico de los yacimientos potásicos de Cardona, Suria, Sallent y Balsareny (Barcelona. España). $\mathrm{PhD}$ Thesis. Universidad de Barcelona. $351 \mathrm{pp}$.

Ramírez, A. (1966). Las Cuencas lignito-uraniferas de Calaf y Ebro-Segre. Energia Nuclear, 10: 458-464.

Ramos-Guerrero, E., Cabrera, L1. and Marzo, M. (1989). Un modelo de sedimentación carbonatada lacustre-palustre en el Eoceno Medio de Mallorca. XI Congreso Español Sedimentologia. $\mathrm{Com}$ - unicaciones: $75-78$.

Regueiro, M., Calvo. J.P., Elizaga. E. and Calderón. V. (1993). Spanish diatomite: geology and economics. Industrial Minerals, 306. March 1993: 57-67.

Reyes. J.L. and Feixas, J.C. (1984). Las pizarras bituminosas: definición. composición y clasificación. I Congreso Español de Geologia. II: $817-827$.

Reyes, J.L., Crespo. V., Feixas, J.C. and Zapata. M.J. (1984). La sedimentación evaporitica en las cuencas neogenas del SE peninsular. $I$ Congreso Espaniol de Geología. II: 803-815.

Reyes, J.L., Zapatero, M.A.. Feixas, J.C. and Avila, J. (1992). El azufre biogénico de las Cuencas Neógenas del Sureste. HI Congreso geológico de España. 3: 410-417.

Rodriguez. P. (1992). Distrito de Mazarrón Zn-Pb-Ag. Mineralizaciones. potencial y trabajos de evaluación. Tierra . Tecnologia, 3: 28--33.

Rosell. L. (1983). Estudi petrológic. sedimentológic i geoquimic de la formació de sals potassiques de Navarra (Eocè superior). PhD Thesis. Universitat de Barcelona, $321 \mathrm{pp}$.

RoselI, L. (1990). La Cuenca Potásica Surpirenaica. In F. Ortí and J.M. Salvany (eds.), Formaciones evaporiticas de la Cuenca del Ebro.. cadenas perifericas, $y$ de la zona de Levante. Universidad de Barcelona: 89-95.

Rubio Navas. J. (1990). Inventario nacional de recursos de estroncio, 1989 ITGE. MIE Madrid, 199 pp.

Salvany. J.M. (1989). Las Formaciones evaporíticas del Terciario continental de la Cuenca del Ebro en Navarra y La Rioja. Litoestratigrafia, petrologia y sedimentologia. PhD Thesis. Universidad de Barcelona, $397 \mathrm{pp}$.

Salvany, J.M. and Ortí. F. (1992). El yacimiento glaubcrítico de Alcanadre: Procesos sedimentarios y diagenéticos (Mioceno inferior. Cuenca del Ebro). In Garcia Guinea and Martinez Frías (eds.). Recursos minerales de España. Textos Universitarios, 15. C.S.I.C.: $1251-1274$.

Salvany. J.M. and Orti. F. (1994). Miocene glauberite deposits of Alcanadre, Ebro basin: sedimentary and diagenetic processes. Spe $i$. Pub/ SEPM, 50: 203-215.

Sánchez Moral, S., Hoyos. M., Ordónez. S., Garcia del Cura. M.A. anù Canaveras, J.C. (1993). Genesis de epsomita infiltracional por dedolomitizacion en ambiente sulfatado árido: efioresencias en la Unidad Inferior Evaporita de la Cuenca de Calatayud. Congrese de Geoquimica de España. Soria, 1993: 24-29.

Santanach. P.. Baltuille. J.M., Cabrera. L1., Monge. C., Sácz. A. and Vidai Romani. J.R. (1988). Cuencas terciarias gallegas relacionadas con corredores de fallas direccionales. / C'ongreso Geologico di España, Simposios: 123133.

Singer, A. and Galản, E. (eds.) (1984). Palygorskite sepiolite:occurrences. genesis and uses. Developments in Sedimentology, 37. Elsevier. Amsterdam, $352 \mathrm{pp}$.

Suarez, F., Armenteros, I., Martín Pozas, J.M. and Navarrete. J. (1989). E. yacimiento de palygorskita de Bercimuel (Segovia): Génesis y propiedades tecnológicas. Estud. Geol. 26: 27-46.

Suarez. F., Flores, L., Añorbe. M., Diez. J.A., Navartete. J. and Martin Po7as, J.M. (1991). Mineralogical and textural characterisation of the Bercimuel Paligorskite (Segovia, Spain). Proc. $7 t h$ Euroclav Conf., Dresden, 1991: 1019-1023.

Utrilla. R., Pierre, C., Orti. F. and Pueyo, J.J. (1992). Oxygen and sulphur isotope composition as indicators of the origin of Mesozoic and Cenozoic evaporites from Spain. Chem. Gool., 102: 229--244.

Vázquez. Guzman, F. (1983). Depósitos minerales de España. IGME. Madrid. $153 \mathrm{pp}$. 